\title{
WestVirginiaUniversity
}

THE RESEARCH REPOSITORY @ WVU

Graduate Theses, Dissertations, and Problem Reports

2015

\section{"The Whistling Wife": Women and Popular Song in the Postbellum American South}

Melanie J. Green

Follow this and additional works at: https://researchrepository.wvu.edu/etd

\section{Recommended Citation}

Green, Melanie J., "'The Whistling Wife": Women and Popular Song in the Postbellum American South" (2015). Graduate Theses, Dissertations, and Problem Reports. 5709.

https://researchrepository.wvu.edu/etd/5709

This Thesis is protected by copyright and/or related rights. It has been brought to you by the The Research Repository @ WVU with permission from the rights-holder(s). You are free to use this Thesis in any way that is permitted by the copyright and related rights legislation that applies to your use. For other uses you must obtain permission from the rights-holder(s) directly, unless additional rights are indicated by a Creative Commons license in the record and/ or on the work itself. This Thesis has been accepted for inclusion in WVU Graduate Theses, Dissertations, and Problem Reports collection by an authorized administrator of The Research Repository @ WVU. For more information, please contact researchrepository@mail.wvu.edu. 


\title{
"The Whistling Wife": Women and Popular Song in the Postbellum American South
}

\author{
Melanie J. Green \\ Thesis submitted \\ to the College of Creative Arts \\ at West Virginia University \\ in partial fulfillment of the requirements for the degree of \\ Master of Music in \\ Music History \\ Travis Stimeling, Ph.D., Chair \\ Evan MacCarthy, Ph.D. \\ William Haller, D.M.A. \\ School of Music \\ Morgantown, West Virginia \\ 2015
}

Keywords: Popular Song, Women, Southern Belle, Nineteenth Century, Gender, American South

Copyright 2015 Melanie J. Green 


\title{
ABSTRACT \\ "The Whistling Wife": Women and Popular Song in the Postbellum American South
}

\begin{abstract}
Melanie J. Green
This study discusses the practice of music-making by middle and upper class women in the nineteenth-century American South, and the ways in which the practice was continued in the decades following the Civil War amid changing class and gender politics. The study examines two sheet music collections, one from the South and one from the North, dating from the 1880s and 1890s. An examination of the content of these collections reveals differing attitudes over changing class and gender politics and acceptable practices for music-making in the North and South. A discussion of these young women and their families tells their stories through the sheet music they left behind.
\end{abstract}




\section{Table of Contents}

Chapter 1: White Middle-class Women and Music in the Postbellum South: Literature Review

I. Gender Roles in the Nineteenth-Century South...........................................

II. General Trends in $19^{\text {th }}-$ Century Popular Song .............................................. 15

III. Women and Music in the Nineteenth-Century South .....................................18

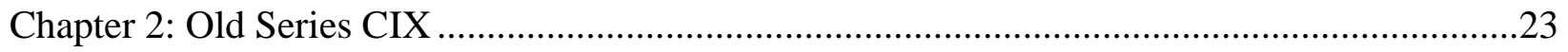

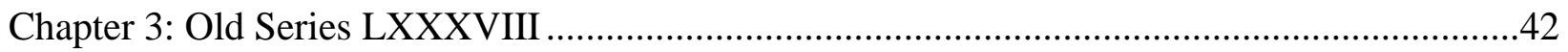

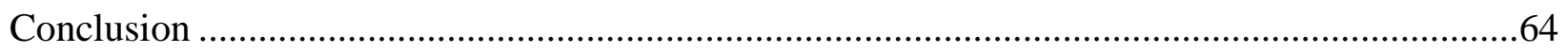

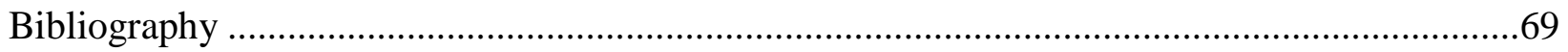




\section{Chapter 1 \\ White Middle-class Women and Music in the Postbellum South: Literature Review}

\section{Gender Roles in the Nineteenth-Century South}

While for many years the issues of slavery, war, and poverty have taken center stage in the literature addressing postbellum social change, changes in gender roles as a result of the Civil War have only been addressed more recently. Issues of femininity, masculinity, motherhood, fatherhood, daughterhood, and the family unit have been the center of postbellum gender studies. The literature explains that antebellum society in the American South held very strict expectations for both men and women of the middle and upper classes. The social order called for specific behaviors from both sexes in their everyday life and interactions. While men held the dominant role in the household and in society, women were considered subordinate to the men in their lives: their fathers, husbands, or other male relatives. Men owned land and participated in politics while women oversaw the running of the household and the raising of children. Concepts of fatherhood and motherhood were clearly defined and valued. Within and without the home, there was a code of behavior that was considered proper, and breaking any of these social rules could result in criticism by one's peers or make one the subject of gossip or a scandal. While these attitudes were, for the most part, retained after the Civil War, there began to be exceptions to social rules that challenged American thinking on the issue of gender in the decades that followed. The following section will outline the arguments made in the most important works of scholarly literature relevant to this study.

Anne Firor Scott's The Southern Lady: From Pedestal to Politics, 1830-1930 discusses the changing roles of the southern woman over a hundred years. As the title indicates, she describes a transformation in expectations of the southern woman over the specified time period. 
She marks the Civil War as a turning point, dividing her book into two parts: The Antebellum Lady and The "New Woman." First published in 1970, Scott's book is one of the first to address the issue of southern women's changing gender roles in the nineteenth century.

Antebellum women were viewed as a "submissive wife whose reason for being was to love, honor, obey, and occasionally amuse her husband, to bring up his children, and manage his household."1 Antebellum women were expected to be modest, beautiful, graceful, self-suffering, and pious, as well as to maintain a certain air of innocence and purity. Scott explains that this image of the southern belle was a myth designed to convince women to adopt these characteristics in order to become the ideal wife for some charming suitor. Scott then describes the reality of southern womanhood, one that was much less attractive. In plantation households, women were afforded the frustrating occupation of managing the household servants or slaves by assigning tasks, dealing out rations, and taking responsibility for their health. ${ }^{2}$ In addition, women were expected to take on a maternal role by bearing and raising children, which in the nineteenth century often meant "endless pregnancies, with attendant illness, and the dreadful fear of childbirth" which could easily end a woman's life. ${ }^{3}$

Women's education, Scott explains, began as an effort to encourage parents to shape their daughters into more interesting young ladies so they could eventually become more interesting wives. Arguments were that "women had undeveloped intellectual capacities, that educated women made better wives and better mothers (and hence a better society), and that educated

\footnotetext{
${ }^{1}$ Anne Firor Scott, The Southern Lady: From Pedestal to Politics 1830-1930 (Chicago: University of Chicago Press, 1970), 4.

${ }^{2}$ Ibid., 36.

${ }^{3}$ Ibid., 37.
} 
women were better companions." 4 Attitudes such as these encouraged women to read and write to elevate their intellectual status. Many women read constantly, usually novels and poetry. Some women wrote their own novels that criticized the woman's role in southern society as too restrictive and revealed general "dissatisfaction with a woman's place in life.",5

Some women used the upheaval of social structures that occurred as a result of the war to remedy this dissatisfaction. Scott explains the many ways southern women became more independent during the Civil War. There are two ways in which this happened. The first is that the men left home to fight in the war, putting women in charge of management of the plantations and other households, something women who were accustomed to plantation life were able to do quite easily, given that there was a long tradition of matronly involvement in the inner workings of plantation life. ${ }^{6}$ The second related to their war efforts. Women took responsibility for organizing and volunteering in soldiers' hospitals, as well as made soldiers' uniforms and campaigned for the Confederate cause. The end of the war called women's roles into question when the surviving men returned home to women who managed to survive the destruction of the war without them. ${ }^{7}$

Scott describes the decades following the end of the war as a time in which there was a "widening gulf between the sexes" over women's appropriate role in society. ${ }^{8}$ Women became more interested in seeking employment, as well as receiving an education. Many women took up writing as a way to earn a livelihood or in addition to another job. They often wrote sentimental

\footnotetext{
${ }^{4}$ Ibid., 71.

${ }^{5}$ Ibid., 76.

${ }^{6}$ Ibid., 82.

${ }^{7}$ Ibid., 100.

${ }^{8}$ Ibid., 100.
} 
fiction and poetry, and some worked for newspapers as journalists or editors. ${ }^{9}$ The final chapters of the book discuss how this new demand for education and employment eventually led to greater independence for women in the South, and she concludes her study with a discussion of these women campaigning for, and winning, the right to vote.

While Scott's study traces the nineteenth-century woman's transition from accomplished housewife to public figure, Nancy Theriot's study, Mothers and Daughters in NineteenthCentury America: The Biosocial Construction of Femininity, explores how women in nineteenthcentury America were defined by the way they embraced motherhood. She describes a trend in expectations of women beginning around 1800, when a woman's value depended increasingly on her ability to give birth to and raise moral children. Middle-class women often became solely responsible for their children's upbringing, creating a family dynamic where the father, though the economic and legal head of the household, was uninvolved in the day-to-day operations of the home and maintained distance from his children until his sons were old enough to learn about the adult world. Motherhood gave women the opportunity to exercise power within the home, a chance that was not available to women outside of marriage at this time. ${ }^{10}$

This "imperial motherhood," as Theriot describes it, led to expectations of certain feminine behaviors. ${ }^{11}$ Mothers were taught to think of their condition as maternal suffering, or an abandonment of their own interests in favor of total devotion to their children. In order to set a good example for her children, a woman was expected to control her emotions and appear kind, gentle, and loving at all times. Anger was seen as one of the most harmful emotions to display

\footnotetext{
${ }^{9}$ Ibid., 119.

${ }^{10}$ Nancy M. Theriot, Mothers and Daughters in Nineteenth-Century America: The Biosocial Construction of Femininity (Lexington: University Press of Kentucky, 1996), 35.

${ }^{11}$ Ibid., 15.
} 
for one's children, and women were instructed to remain silent or leave the room whenever they felt angry. Contemporary literature on marriage and child-rearing, such as Lydia Child's The Mother's Book and women's magazines, cautioned against the dangers of showing anger, often asserting that it was unnatural for women to feel anger. ${ }^{12}$ The image of the mother as an embodiment of self-abandonment and suffering for the sake of her children was celebrated in the advice literature written for nineteenth-century women. ${ }^{13}$

By the 1880s, increased industrialization and urbanization in America brought many social changes, including those related to gender roles. The war and the years following it necessitated that women become more involved in the public sphere and in some cases to seek employment. The end of the century saw a fifty percent increase in women enrolled in colleges, which led to the availability of more jobs for educated women. Single women were allowed alternatives to marriage and child-rearing and this changed the way motherhood was viewed by society. ${ }^{14}$ The freedom of choice over the direction of her life led the late nineteenth-century women to question the social structures of motherhood and demand change. Women who chose to marry wanted more control in their marriages. Divorce law reform made it easier for a couple to separate and led to more women taking control of their marital satisfaction by having the option of divorce available to them. ${ }^{15}$ Though birth control options were available since the beginning of the nineteenth century, they were not widely used by married women until the final decades when women felt empowered to control their own fertility. ${ }^{16}$ Another attitude that began

\footnotetext{
${ }^{12}$ Ibid., 22.

${ }^{13}$ Ibid., 23.

${ }^{14}$ Ibid., 78.

${ }^{15}$ Ibid., 80.

${ }^{16}$ Ibid., 91 .
} 
to change in the last few decades of the nineteenth century was the idea that women's bodies were frail by nature, especially in pregnancy. Pregnancy, which was often viewed as a type of illness until this time, was embraced by many women as a natural and healthy process that should not confine a woman to her home or bed under normal circumstances. ${ }^{17}$ Contemporary writing on women's health described new standards of feminine beauty as strong and healthy rather than passive and sickly as before. ${ }^{18}$

While Theriot describes changes in gender roles in the nineteenth century in terms of society's perceptions of women's bodies, LeeAnn Whites approaches the subject of changing gender roles from a social and political standpoint. Theriot also presents what appear to be nationwide trends in gender roles, while Whites focuses her study on the American South. In Gender Matters: Civil War, Reconstruction, and the Making of the New South, Whites casts the Civil War and the years following it as a crisis in gender, especially in the American South. She argues that issues of gender and sexuality are vital to understanding the making of the New South. ${ }^{19}$ Her first chapter, titled "The Civil War as a Crisis in Gender," explains the social upheaval in the South brought on by the war and its implications for gender roles.

Whites begins by explaining the antebellum family structure, one that relied on slavery to define gender roles within plantation households. It seems the primary goal of the men's social code before the war was to remain in a position of dominance and give the appearance of being in control of one's property, family, and finances at all times. For members of the planter class, this meant providing not only for one's own biological family, but for the well-being of the

\footnotetext{
${ }^{17}$ Ibid., 97.

${ }^{18}$ Ibid., 85 .

${ }^{19}$ LeeAnn Whites, Gender Matters: Civil War, Reconstruction, and the Making of the New South (New York: Palgrave, 2005), 2.
} 
plantation and its often-enslaved workers. A plantation owner assumed a fatherly role over his own wife and children as well as his slaves. He was ultimately responsible for their financial and physical security. Slave ownership empowered southern men, especially during times of economic growth when plantations, especially those growing cotton, were particularly successful. $^{20}$

When a woman consented to marry, she was giving up any personal freedoms she had as a single woman (though these were limited as well) in exchange for the security her husband could provide for her. For planter class women, this meant the rest of her life would be devoted to the care of children and the plantation household, which included overseeing house servants and ensuring that the plantation home ran smoothly. Just as her husband assumed a fatherly role over the plantation, she took on a motherly role as the female head of the plantation. Though this may seem like the position of power, her independence was limited. Other than giving orders to house servants, she really had little power in her own home. Because her husband provided her with protection, she was expected to follow his wishes. ${ }^{21}$

Whites attributes the changes in southern gender politics mainly to the war and describes a shift in women's dependence on men after the onset of the war. While women had little or no social, political, or financial power before the war, they had this power thrust upon them while the men were away. Southern women especially embraced this newfound independence by becoming activists for the Confederate war effort. ${ }^{22}$ Feminine pastimes such as novel-reading and piano-playing were replaced by home manufacturing of soldier's uniforms, blankets, and

\footnotetext{
${ }^{20}$ Ibid., 13.

${ }^{21}$ Ibid., 15.

${ }^{22}$ Ibid., 20.
} 
Confederate flags. Some women also volunteered as nurses for wounded soldiers. Ladies Aid Societies were formed to organize the activities that contributed to the war effort. Women who had previously engaged only in domestic activities were now participating in public life. This was socially acceptable because they were doing it to serve their men and the Confederacy. ${ }^{23}$

The expectation that women maintain ladylike behavior at all times was relaxed to some extent during the war years. Women who did what was necessary to support their families and the Confederacy — even if this included manual farm labor or leading a public organizationwere not chided for their actions by other southern women. Women in the North however, did not embrace the war effort with the same zeal and often criticized southern women's behavior as unwomanly. ${ }^{24}$ There was a movement in the North to try to convince Northern women to be more enthusiastic about the war effort. This happened mid-war when it was believed that the South was having success because of the support their soldiers received from home. Although the North never achieved the same outcome as the South in terms of gaining women's interest in the war effort, it did lead to the formation more women's organizations. The disinterest of Northern women may have been due to their disdain for the unladylike behavior of southern women and also because they did not experience the devastation of wartime as much as those in the South. ${ }^{25}$

Whites also discusses a new concept of motherhood that developed at the beginning of the war. Many Confederate women saw it was their duty to encourage their sons to join the army. Giving up one's children to the Confederacy was seen as the height of devotion to the

\footnotetext{
${ }^{23}$ Ibid., 21.

${ }^{24}$ Ibid., 35 .

${ }^{25}$ Ibid., 44.
} 
cause of preserving the way of life in the South. The sacrifice mothers made in sending their sons to war was met with admiration within their social circle, and young men who did not enlist showed disrespect to their mothers. Letters in newspapers of the time emphasized the humiliation young men would bring upon themselves and their mothers by not enlisting. Whites points out that this new attitude brought motherhood out of its domestic cocoon and into the political sphere. $^{26}$

Whites also explains the changes in male gender roles after the onset of the war. Men were used to being the sole authority in their households before the war. The head of a plantation was seen as a father figure for not only his own family, but for his slaves and workers as well. In many ways, men who owned plantations represented southern fatherhood at its core. The head of the plantation made all of the financial decisions, such as those involving the purchase of slaves and sale of crops, and he also settled disputes and acted as disciplinarian. ${ }^{27}$ After the war, however, men came back to find the situation quite different. The women that they had left behind in had in the meantime learned to operate the households without them as well as participate in politics by way of women's organizations. Fortunately for male pride, after the war, many of these organizations devoted themselves to rebuilding southern manhood during Reconstruction. They gave public speaking, financial, and negotiating duties to men to restore a sense of the old society before the war. Men perhaps needed this ego boost after coming back to a home that had been torn apart. Plantations lay in ruins, slavery was abolished, and men had to deal with a sense of defeat after fighting hard for their values and then losing the war. ${ }^{28}$

\footnotetext{
${ }^{26}$ Ibid., 20.

${ }^{27}$ Ibid., 86 .

${ }^{28}$ Ibid., 90 .
} 
Whites then addresses women's willingness to let their new-found independence go after the war. Many women were happy to return to their former status as the subordinate wife once the men returned. This can perhaps be attributed to nostalgic feelings for the Old South or a desire for society to return to its former order as quickly as possible. Women of the day might have said that they acted as they did during the war out of necessity. Though they were happy to resume their dependent role after the war, many women found that the South as they knew it would never be the same. ${ }^{29}$ While many women did turn back to domesticity after the war, others carried on with their newfound independence. ${ }^{30}$

Independence was thrust upon some women because the war left them without male relatives, but others, particularly single women in urban areas, enjoyed their independence and avoided marriage to keep it. Christine Jacobson Carter explains a trend among unmarried women in the nineteenth century toward independence and the avoidance of marriage. This trend started at the beginning of the century and had become a common attitude by the time of the Civil War. In the antebellum South, some single urban women chose not to marry but to spend their time contributing to the betterment of society through social and charitable organizations. Carter's study focuses on women of Charleston, South Carolina and Savannah, Georgia, where this was common. Women of means who lived in urban areas and were supported by fathers, brothers, or uncles who earned a comfortable living, were under less pressure than rural women of the South

\footnotetext{
${ }^{29}$ Ibid., 91.

${ }^{30}$ In the later chapters of her book, Whites describes the career and efforts of Rebecca Latimer Felton, the first female United States senator. Whites explains the significance of her political career after the war and points out the dissonance between her support of women's suffrage and upholding of the subordinate role of women in families. Felton blamed men for the destruction of the Civil War and believed empowering southern white motherhood would lead to a successful society.
} 
to find husbands, so they often chose to remain unmarried. This allowed for the creation of women's organizations dedicated to promoting some kind of civic good. These women spent their time trying to be "useful" since they were not marrying or running a farm or plantation like rural women. This kind of civic engagement was not seen until the war years in other parts of the South, but seems to have happened earlier in Charleston and Savannah. ${ }^{31}$

Though most of Carter's study covers the antebellum years, she explains how these women's lives changed during and after the war. There was more pressure for these women to marry immediately before the war and many of them did. After the war, this sentiment continued, especially in Charleston because of the damage it suffered physically and economically, and the lifestyle of the single woman became less affordable. The problem was that there were fewer men who were well and willing to marry after the war. For many unmarried women, this meant they had to find a way to support themselves, usually just in part because they were still living with family members. The unmarried woman's value of being useful during an economic crisis meant finding work for which they could be paid rather than the charity-like work they had done in the past. Many single women became teachers because they were already well-educated and this kind of a job seemed more appropriate for their social status than other kinds of labor. Some women, however, did have to find work cleaning or sewing, especially at the end of the war after slaves were emancipated, even if it meant just helping out in their own homes instead of working for a wage. ${ }^{32}$

\footnotetext{
${ }^{31}$ Christine Jacboson Carter, Southern Single Blessedness: Unmarried Women in the Urban South, 1800-1865, (Urbana: University of Illinois Press, 2006).

${ }^{32}$ Ibid., 150.
} 
In The Reconstruction of White Southern Womanhood, 1865-1895, Jane Turner Censer discusses the transition in women's roles following the war in terms of how women were perceived by society, domestic expectations, changes in property law that allowed women to obtain property, schoolteaching, and women's authorship. Her book takes a close look at the era following the Civil War and traces the way women's lives changed before and after the war. Her study serves to explain changing gender roles as well as paint a picture of the lives of women in the southern white elite class.

In the first chapter of her book, Censer describes the construct of the Southern Belle and how it was changed after the Civil War. She explains the typical curriculum for young women, which included education in "English grammar and composition, history, natural sciences, mathematics, and moral philosophy" as well as "music, embroidery, and more esoteric arts and crafts, such as netting, china painting, and the like."33 A truly accomplished young woman would be proficient in music, art, and foreign languages. These accomplishments were held in high esteem by the society in which these white elite women lived. After the war, parents had other reasons for wanting to educate their daughters in music and the arts. They hoped that by providing their daughters with a good education, one that included music and art, they might be able to earn a wage as competent and well-rounded teachers. Censer describes this as a marked difference from the attitudes of the antebellum period, when an education in the arts served merely to elevate a young woman's social status. Censer goes on to explain that this elevation of social status was important after the war as well to retain class distinctions. ${ }^{34}$

\footnotetext{
${ }^{33}$ Jane Turner Censer The Reconstruction of White Southern Womanhood, 1865-1895 (Baton Rouge: Louisiana State University Press, 2003), 15.

${ }^{34}$ Ibid., 17.
} 
Censer notes that changes in domesticity were especially marked in the South after the war. Women who had previously served as the female head of plantations — or who had seen their mothers do so-were forced to redefine their roles after emancipation. Women had to learn to navigate new expectations regarding giving orders to servants rather than slaves and, in cases where servants were not afforded, do housework themselves. ${ }^{35}$ The postbellum household saw some changes after the war as well. Fewer children, especially daughters, were leaving the home, which led to multigenerational households where children would live with their parents instead of setting off on their own, even when they married. Co-residence of siblings was also common. These arrangements were usually due to financial strain, but led to a redefinition of familial roles that further complicated the new domesticity. ${ }^{36}$

The number of women schoolteachers increased after the Civil War. Censer explains that this increase was not caused by the war, but that changing attitudes led to an acceptance of schoolteaching as an occupation for women. In addition to the newfound need to earn a wage after the war, teachers were in greater demand because of the growing number of public and private schools. This provided an outlet for women who sought to do something other than marry and take on a domestic role. Women were able to support their families financially, as well as participate in an environment that celebrated for their intellectual prowess and that earned them a good deal of respect as public figures. Censer states that this provided women who did not wish to marry with "a meaningful place in society."

In Within the Plantation Household: Black and White Women of the Old South, Elizabeth Fox-Genovese explains gender politics in the antebellum South. Her study covers the historical

\footnotetext{
${ }^{35}$ Ibid., 51.

${ }^{36}$ Ibid., 54.
} 
period leading up to the Civil War, laying out the social structures having to do with women and their place in society that would come into question after the war. Fox-Genovese discusses gender in terms of how it relates to class and race, asserting that gender cannot be understood without keeping these in mind. ${ }^{37}$ Her book includes chapters on slaveholding women (the white wives and daughters of plantation owners) and slave women (the black women who worked for them). She also considers women of the yeoman, middle, and poor white classes and explores how class differences set them apart from the slaveholding women. She uses evidence written in diaries, letters, and other family papers of southern women from the Old South to illustrate her assertions. Fox-Genovese's study has been cited by other scholars in nineteenth-century gender studies as one that lays the foundation for an understanding of the complex social conditions of the antebellum South.

Catherine Clinton and Nina Silber have created a similar study to Fox-Genovese's in Divided Houses: Gender and the Civil War. This essay collection includes chapters covering issues of gender, race, class during the war years and Reconstruction. It covers such topics as men's gender roles as they related to soldiering, gender roles among African American men after emancipation, women as supporters of the Confederate and Union war causes, and gender roles among freed slaves. Though their study is not limited to the South, the scholarship contained within it provides insight into gender roles across the nation during the Civil War. Like FoxGenovese's study, it has served as a starting point upon which several other scholars have built their own research.

\footnotetext{
${ }^{37}$ Elizabeth Fox-Genovese, Within the Plantation Household: Black and White Women of the Old South (Chapel Hill: University of North Carolina Press, 1988), 43.
} 
As the literature indicates, the years following the Civil War were a time of great change in terms of gender politics. Scholars have viewed this change under several lenses, but many of them, especially Anne Firor Scott and LeeAnn Whites, seem to have come to the conclusion that the Civil War provided women with an opportunity to seek independence and become active politicians and public figures. This newfound independence did not come easy and many southern women clung to antebellum traditions during this uncertain time. This idea will be explored in greater depth in Chapter 2.

\section{General Trends in $19^{\text {th }}$-Century Popular Song}

The second and third chapters of this study examine two postbellum sheet music collections compiled by young women and preserved in the Nineteenth-Century American Sheet Music Collection at the University of North Carolina at Chapel Hill. Much of the music in this collection consists of popular songs and piano pieces printed by prominent publishers in cities such as New York and Boston and purchased for individual use by young women to be played or sung at home. Sheet music played an important role in American culture, especially in the nineteenth century, when the sheet music printing industry was at its height. Popular song in particular was composed and marketed by music publishers with profits in mind, so songs were written for a mass audience by appealing to their interests. ${ }^{38}$ Several scholars have traced trends in popular song in the nineteenth century.

One monumental work on American song is Charles Hamm's Yesterdays: Popular Song in America. This work provides on overview of popular songs in America from the British songs that were popular in the 1770s to the rock and roll of the 1960s and 70s. There are several chapters that are relevant to this study including chapters on Civil War and postwar songs, and to some extent chapters on Stephen Foster and Tin Pan Alley. The appendices in this book provide

\footnotetext{
${ }^{38}$ Charles Hamm, Yesterdays: Popular Song in America (New York: Norton, 1979), xvii.
} 
lists of the most popular songs at various points in American history. Chapter 12, titled " "The Old Home Ain't What It Used to Be' or American Song in the Postwar Years" is most relevant to my study. Hamm describes the postwar years as a quiet period in American culture. ${ }^{39} \mathrm{He}$ explains that the songs written after the war do not provide much insight into the social and political difficulties of the time. Though the postwar years were a time of major adjustment for the North and South alike, Hamm asserts that the songs of the time do not reflect this. Songs from the end of the nineteenth century were often written by people in the northern, eastern, and western regions of the United States, while very few came from the South. Hamm explains that songs from this period are typically centered around themes of love and nostalgia, perhaps in longing for the simplicity of prewar days. He says the songwriters of the late nineteenth century turned away from contemporary issues and conflicts and wrote songs in this reminiscent style as a form of escapism. ${ }^{40}$

Another important study on popular song is Jon W. Finson's The Voices That Are Gone: Themes in Nineteenth-Century Popular Song, which explores broad themes in American song, including love, courtship, and death. Finson provides the historical context for these themes as well as provides several examples of them in song. For instance, Finson explains that themes of death were so present in popular song during the nineteenth century because death, especially premature death, was an unavoidable reality for families during this era. ${ }^{41}$ These themes are ubiquitous in the songs of the collections I have chosen for this study, and are discussed at length in the following chapters. He also discusses the racial implications of blackface minstrelsy

\footnotetext{
${ }^{39}$ Ibid., 254.

${ }^{40}$ Ibid., 254.

${ }^{41}$ Jon W. Finson, The Voices That Are Gone: Themes in Nineteenth-Century Popular Song (New York: Oxford University Press, 1994), 83.
} 
throughout the century and the songs that came from the practice. He explains that blackface minstrelsy remained a popular form of entertainment after emancipation because northerners sought "the exoticism blackface still provided." 42 These songs tended to appear in two forms: nostalgic songs that depicted the mythological rural South and its plantation slaves ${ }^{43}$, and songs that imitated black spirituals. ${ }^{44}$ Both types of songs were printed and disseminated widely, especially to people of the North. Several of these songs can be found in the music collection discussed in the third chapter of this study.

In Dreaming of Dixie: How the South Was Created in American Popular Culture, Karen L. Cox discusses broad trends in American culture that celebrate the South. She covers several aspects of culture, including popular song, advertising, radio, film, and literature. She explains the American fascination with "Dixie" that began in the nineteenth century and can be traced throughout the twentieth century. In her introduction, she lays out several southern icons that feature prominently in these cultural trends: "the Confederate colonel, the mammy, the belle, the opulent plantation big house, bolls of cotton, and the hillbilly." 45 Several of these are celebrated in nineteenth century song about the South, such as Stephen Foster's nostalgic song, “Old Folks at Home." 46 In her chapter on popular song, Cox traces the presence of "Dixie" in Tin Pan Alley songs in the late nineteenth and early twentieth centuries.

\footnotetext{
${ }^{42}$ Ibid., 200.

${ }^{43}$ Ibid., 201.

${ }^{44}$ Ibid., 209.

${ }^{45}$ Karen L. Cox, Dreaming of Dixie: How the South Was Created in American Popular Culture (Chapel Hill: University of North Carolina Press, 2011), 7.

${ }^{46}$ Ibid., 11.
} 


\section{Women and Music in the Nineteenth-Century South}

Candace Bailey's study on women and music in the antebellum South, Music and the Southern Belle: From Accomplished Lady to Confederate Composer ${ }^{47}$ provides a wealth of information concerning the women's music education and the social expectations surrounding it. The study culminates in a discussion of women's composition and music publications leading up to the Civil War. Bailey has examined music collections of various southern women, some of which are contained in the Nineteenth-Century American Music Collection at the University of North Carolina at Chapel Hill alongside collections I have viewed for this study. I intend to add to Bailey's work by examining music collections from the postbellum period to point out the change in social attitudes that can be drawn from them. Bailey's study also serves as a starting point for my own research by explaining the social conditions of the time immediately preceding the time of my own study.

According to Bailey, music was considered to be an essential part of the middle-class southern woman's education as she was growing up. Music instruction happened in a variety of ways. Instruction on the piano by a child's mother could begin early in the child's life. Once a woman married and had children, it was expected that she herself cease entertaining guests in her home with her musical skills, but it was also still acceptable for her to pass along her knowledge to her children. Once a child reached a certain age or skill level, she was more likely to begin studying with a private instructor, governess, or at a school. Private instruction was offered by both male and female teachers at a variety of rates and might have taken place inside or outside

\footnotetext{
${ }^{47}$ Carbondale: Southern Illinois University Press, 2010.
} 
of the pupil's home. Instruction by a governess usually included education in subjects other than music, with music being only a part of a broader curriculum. ${ }^{48}$

In several places, young ladies had the option to attend a boarding or day school to receive music lessons. Depending on the school's policies or the family's financial situation, music lessons given at schools could also happen in a variety of ways. Young women could attend school as boarders and take lessons on piano, voice, or other instruments as part of a curriculum that included instruction in other subject areas: writing, arithmetic, painting, etc. Alternatively, young women could attend school part-time for music instruction only. Though the rates for music lessons were typically much higher than instruction in any other subject, this was the solution for families who wanted their daughters to receive a musical education but could not afford the boarding school, of families that preferred to educate their daughters in other subjects at home. Rates for piano lessons were much higher than those for voice lessons, though many students studied both. ${ }^{49}$ At the end of each term, it was common for a school to hold a recital for the students to show their parents what they had learned. It is important to note, however, that these recitals were not intended as an opportunity for the students to "perform" and show off skills, but rather as a way to show the progress of each pupil. ${ }^{50}$

There were limitations to the technical prowess young ladies were expected to possess when it came to their piano playing. Since they learned the piano not to perform but to be able to entertain family and guests at home without drawing too much attention to themselves, certain pieces and techniques were off-limits for those wishing to preserve their respectability. Piano

${ }^{48}$ Candace Bailey, Music and the Southern Belle: From Accomplished Lady to Confederate Composer (Carbondale: Southern Illinois University Press, 2010), 65.

${ }^{49}$ Ibid., 65 .

${ }^{50}$ Ibid., 75 . 
repertoire for young women tended to be written within a set of boundaries. Once a certain level of technical proficiency was reached, the piano student was not able to progress any further without looking for pieces outside of the acceptable repertoire. She then ran the risk of being seen as too ambitious in her musical goals, and the last thing any young lady wanted was to be thought a show-off. ${ }^{51}$

Women were also restricted in their piano playing because of their wardrobe and what was expected of them in terms of decency. The dresses worn by young women of the middle class allowed for very little movement from the waist up, and often the sleeves were constructed so that arm movement was limited. This would have made virtuosic playing very difficult even if it were socially acceptable. Piano techniques of such as hand-crossing would have been difficult if not impossible and would have come across as too showy anyway. Too much body movement would have been viewed as showing off as well and was discouraged. Arrangements and compositions for one piano and four hands would only have been acceptable if played by two women, as playing them with a male teacher was considered to be too intimate due to the physical proximity required to execute such works. ${ }^{52}$

In the nineteenth-century South there existed this concept of the "piano girl" as Bailey describes in the fifth chapter of her book. A well-educated young woman of the upper classes would spend at least three hours a day practicing the piano, though she was never considered to be a great musician or artist. This concept was most popular before the Civil War, though those who were able continued to practice and study during the war. Bailey explains that the image of the piano girl was especially meaningful in the South, and explains that it was common

\footnotetext{
${ }^{51}$ Ibid., 93.

${ }^{52}$ Ibid., 98.
} 
practice - even during wartime - for young women to include notations about how they were making progress on the piano in their letters to friends and family. ${ }^{53}$

The typical antebellum music collection consisted of music for piano or piano and voice. Many of the solo piano pieces were polkas, waltzes, quadrilles, and schottisches. It is interesting that these dance forms appear in the piano repertoire, because it was generally frowned-upon for young women to dance polkas at public dances. The quadrille was the most acceptable danceform, followed by the schottische, and waltzes and polkas were considered daring or unacceptable. ${ }^{54}$ Southern sheet music collections tend to lack what we would consider standard piano repertoire today. One does not usually find a Beethoven sonata in a music collection from the nineteenth century for several reasons. Bailey explains that women tended to collect music that was popular, rather than sophisticated. Piano works by prominent composers in the classical music sphere were not generally collected by young southern women because they were not considered fashionable. Another reason is that compositions by composers such as Beethoven were considered "too masculine in conception," and therefore unacceptable (and probably too difficult) for young women to play. ${ }^{55}$

In addition to piano music, many antebellum music collections contained vocal music. Bailey divides the vocal music into two categories: popular songs and arias from popular operas. Of the popular songs, many of them were written by contemporary American composers, and more rarely English composers and collections of German Lieder. ${ }^{56}$ Of the arias, many of them are arrangements of arias from Verdi's operas. Since the bel canto style of singing would have

\footnotetext{
${ }^{53}$ Ibid., 97.

${ }^{54}$ Ibid., 95.

${ }^{55}$ Ibid., 96.

${ }^{56}$ Ibid., 122.
} 
been too difficult for most of these women to sing, simpler arrangements were made, sometimes translated to English, to accommodate a less studied pupil. ${ }^{57}$

Bailey's study covers the period of time leading up to that of this study, and provides the historical context for women and their music collections in the nineteenth-century South up until the Civil War. In my study, I intend to pick up where Bailey has left off by examining music two music collections found in the Nineteenth-Century American Sheet Music Collection at the University of North Carolina at Chapel Hill. Both appear to have been compiled during the 1880s and 90s, one of them having been the collection of a southern family with seven daughters, and the other the collection of an only child from the North. From the contents of these collections, several conclusions can be drawn about the type of music that was popular during this period, the probable social standing of the families these women came from, and general differences between the two collections that can be attributed to the owners' location in the United States.

My method in examining these music collections was to view the digital images of the sheet music looking for handwritten names. I took these names and searched for them in census and public records to determine who the owners of the collections were. I used the information I found about their families and social statuses as well as the content of their sheet music collections to piece together a picture of who these young women were, and it is my hope that in doing this I have given these women voices by making their stories known.

${ }^{57}$ Ibid., 124. 


\section{Chapter 2 Old Series CIX}

The Nineteenth-Century American Sheet Music Collection at the University of North Carolina at Chapel Hill contains a volume of sheet music that is of special interest to this study. Old Series volume CIX contains twenty-seven pieces of sheet music. Most of them were published between 1870 and 1900, but there are a few published before and during the war years. The reason I chose to include this volume in the study is because it represents the time period at which I am looking, whereas many other volumes in the collection represent an earlier time period. Also of interest in this volume are two songs that communicate social and political concerns of this time period. These songs, "The Whistling Wife" by Harry Randall and "Free Coinage of Gold and Silver at 16 to 1" by J.P. Tingen, will be discussed later in this chapter.

There are a few notations on pieces of sheet music within the collection that indicate who owned it. Three names that appear are Nina Horner, Lucy Horner, and Sophronia Horner. A search for these names in census records revealed this collections' connection to the Horner family, a prominent North Carolina family with several daughters. James Hunter Horner (18221892) and his wife Sophronia Moore Horner (1829-1909) lived in the city of Oxford in Granville County ${ }^{58}$ Though the family was by no means wealthy after the Civil War, they did represent a

\footnotetext{
${ }^{58} 1860$ U.S. Census, Granville County, North Carolina, population schedule, Oxford, p. 451, dwelling 70, family 170, James H. Horner; digital image, Ancestry.com, accessed 4 Nov. 2015, http://ancestry.com. 1870 U.S. Census, Granville County, North Carolina, population schedule, Oxford, p. 296A, dwelling 208, family 211, James H. Horner; digital image, Ancestry.com, accessed 4 Nov. 2015, http://ancestry.com. 1880 U.S. Census, Granville County, North Carolina, population schedule, Oxford, p. 536B, dwelling 145, family 168, James H. Horner; digital image, Ancestry.com, accessed 4 Nov. 2015, http://ancestry.com.
} 
certain amount of respectability in their community. Laura F. Edwards describes the Horner family as belonging to a community of "white elite" families in postwar Granville County. ${ }^{59}$ This respectability was probably due to James Horner's status as a teacher and headmaster. He held an M.A. and an honorary LL.D. from the University of North Carolina. He founded the Horner Military School, which operated from 1851 to 1920 . Preferring to teach his own school, he refused offers to teach at the University of North Carolina. ${ }^{60}$ James Horner was also an ardent secessionist. At the onset of the war, he organized a Confederate company, the Granville Grays, and later served as a captain in the North Carolina $23^{\text {rd }}$ Infantry Regiment. Though he later came to question his involvement in the war, he was passionate about the Confederate cause. ${ }^{61}$

The Horner family had three sons: James Pulliam Horner (b. 1852), who died in childhood; Jerome Channing Horner (1853-1951); and Junius Moore Horner (birth and death dates unknown). The latter two sons took over the Horner Military School after their father's death. Census records from 1860-1900 indicate that there were seven daughters: Lucy Anna Horner (1855-1935), Mary Ellen Horner (1857-1922), Sophronia Moore Horner (1861-1913), Bettie Gertrude Horner (1863-1881), Julia Emma Horner (1866-1944), Nina Horner (1868-

1900 U.S. Census, Granville County, North Carolina, population schedule, Oxford, p. 19A, dwelling 381, family 426, Sophronia Hirum [Sophronia Horner]; digital image, Ancestry.com, accessed 4 Nov. 2015, http://ancestry.com. ${ }^{59}$ Laura F. Edwards, Gendered Strife and Confusion: The Political Culture of Reconstruction (Urbana: University of Illinois Press, 1997), 111.

${ }^{60}$ William S. Powell, “Horner, James Hunter,” NCPedia, http://ncpedia.org/biography/horner-james-hunter (accessed 4 Nov. 2015).

${ }^{61}$ Edwards, 113. 
1955), and Daisy Louise Horner (1871-1937). ${ }^{62}$ Several of these daughters married when they were in their late teens or twenties, but a census record from 1900 indicates that Mary and Nina remained unmarried at ages forty-two and thirty-eight, respectively, and lived with their widowed mother. ${ }^{63}$ Other records indicate that Nina married William Sinkler Manning later in her life to act as mother to his children from a previous marriage. ${ }^{64}$ Mary's gravestone indicates that she was once a school teacher. ${ }^{65}$

Though Horner and his sons are celebrated in literature about Granville County and its residents, it is the women of the family that are of particular interest to this study. Edwards describes Horner's wife, Sophronia, as the embodiment of postwar feminine ideals for the white elite social class. Her views on her society and a woman's place within it are evident in letters she wrote to her husband during the war years and afterward. Edwards compares Sophronia's life to a story published in an Oxford newspaper called "Annie the Butterfly." In the story Annie comes to represent the ideal feminine qualities of unselfishness and service to her family in the throes of postwar hardship. The story was published in the Oxford Torchlight in 1875 and was one of many stories designed to instruct elite white men and women about their new roles in the

\footnotetext{
62 “James Hunter Horner,” Find a Grave, http://www.findagrave.com/cgibin/fg.cgi?page=gr\&amp;GRid=28360559\&amp;ref=acom (accessed 4 Nov. 2015).

${ }^{63} 1900$ U.S. Census, Granville County, North Carolina, population schedule, Oxford, p. 19A, dwelling 381, family 426, Sophronia Hirum [Sophronia Horner]; digital image, Ancestry.com, accessed 4 Nov. 2015, http://ancestry.com. 641910 U.S. Census, Spartanburg County, South Carolina, population schedule, Spartanburg Ward 1, p. 6B, dwelling 92, family 106 , William S. Manning; digital image, Ancestry.com, accessed 4 Nov. 2015, http://ancestry.com.

65 “Mary Ellen Horner,” Find a Grave, http://www.findagrave.com/cgibin/fg.cgi?page=gr\&amp;GRid=28343583\&amp;ref=acom (accessed 4 Nov. 2015).
} 
post-emancipation South. ${ }^{66}$ Women were instructed to abandon frivolity in favor of economy in their homes. For many women this meant taking on more housework themselves instead of hiring help. For some women, it meant taking on cleaning or sewing jobs to supplement the household income. This change created some insecurity for the elite whites. Class distinctions that were once solidly in place were now less apparent as many families lost much of their wealth. Some women feared that they would be confused with poor whites if they worked for income or did their own housework, so the idea that they were doing it for the good of their families was a necessary construct to keep the separation between themselves and the lower classes in place. $^{67}$

This idea that women should be self-sacrificing and devote their efforts to making a comfortable home in times of economic hardship must have influenced the Horner daughters' upbringing. According to letters she wrote to her husband, Sophronia Horner worked hard to distinguish class and race lines in her household. In 1861, a child was born to Susan, one of the slave women in the household, but she and others observed that the child was especially fairskinned. Sophronia must have had her own suspicions about the child's parentage, but she pushed these thoughts aside and treated the child as one of the slave class. ${ }^{68}$ Observance of class and race lines probably meant that the Horner daughters had to go to extra trouble to distinguish themselves from members of the lower classes. The existence of their music collection suggests that the celebrated ladylike skills of piano-playing and singing were one way that they did this.

\footnotetext{
${ }^{66}$ Edwards, 108.

${ }^{67}$ Ibid., 116.

${ }^{68}$ Ibid., 112.
} 
Old Series CIX contains pieces of sheet music bearing the names of Lucy, Sophronia, and Nina. On other pieces the name "Miss Horner" is written, and most of the pieces contain no name at all. There are seven pieces in the collection that were published as part of a sheet music journal called the Boston Weekly Journal of Sheet Music. These pieces were published by F. Trifet of 36 Bromfield Street in Boston. The journal was active in the 1890s, as indicated by the publication dates on the pieces in this and other collections, and sent pieces of sheet music to its subscribers each week for the fee of one dollar a year. Each piece in Old Series CIX is marked with the date around which the subscriber would have received it. The dates in Old Series CIX range from September 1895 to January 1899. It seems unlikely that the Horners had a subscription to the journal because the pieces in their collection are few and dated at least several months apart from each other. It is possible that they were able to purchase them individually, or that the pieces were given to them by someone who had a subscription. Another name that appears on one of the pieces is Mollie Pescud, who was possibly a friend of the Horner daughters who exchanged sheet music with them. A census record from 1880 indicates that a Mollie Pescud close in age to the older Horner daughters lived in Raleigh, but whether this is the correct Mollie Pescud is uncertain. ${ }^{69}$

These are the pieces from the Boston Weekly Journal of Sheet Music in the Horner collection, listed chronologically by publication date: "Keep the Horseshoe over the Door" (September 18, 1895), "Precious Treasure” (May 20, 1896), “Old Folks at Home” (February 10, 1897), “Tread Softly, the Angels Are Calling” (May 19, 1897), "Request” (December 1, 1897),

\footnotetext{
${ }^{69} 1880$ U.S. Census, Wake County, North Carolina, population schedule, Raleigh, p. 266, dwelling 163, family 194, Mollie J. Pescud; digital image, Ancestry.com, accessed 4 Nov. 2015, http://ancestry.com.
} 
"The Whistling Wife" (November 16, 1898), and "She Sleeps Among the Daisies" (January 11, 1899). Interestingly, none of the pieces published by this journal bear the names of any of the Horner women like some of the other pieces in the collection, which suggests they were either shared by all of the daughters, given to them by someone else, and/or they were not favorite pieces worthy of writing one's name on them. The songs published by this journal seem to have been reprints of previously published material, as the songs in the Horner collection all list copyright dates before the 1890s. One song, "Tread Softly the Angels Are Calling," includes an advertisement for the journal explaining what the publishing company has to offer, including large volumes of sheet music published monthly which promises "96 to 128 pages of music, no reading matter, society 'gush', or trade 'puffs'," the weekly subscription, and music available for individual purchase.

The collection also includes several pieces of music that were popular during the nineteenth century. These are Stephen Foster's “Old Folks at Home," Louis Dela's “The Ring My Mother Wore," and Will S. Hays's "Write Me a Letter from Home." These pieces are present in several other binders in the Nineteenth-Century American Sheet Music Collection. This is perhaps because themes expressed in these songs resonated with people in the South in during and after the war. All communicate nostalgia for times past or sorrow over the death of loved ones.

"Write Me a Letter from Home," written in 1866, is said to have sold over 300,000 copies. According to Charles Hamm in Yesterdays: Popular Song in America, Will S. (William Shakespeare) Hays was one of the most important songwriters in the years following the war. Hays was known for his minstrel songs as well as his sentimental verse-chorus songs. Hays was a self-taught musician from Louisville earned a living as a writer for the Louisville Courier- 
Journal. Though Hays was a Unionist during the war, he wrote songs that express both northern and southern attitudes. ${ }^{70}$ The lyrics of "Write Me a Letter from Home" convey the speaker's yearning for a letter from loved ones while he is away from home. Though the song does not state the reason for the speaker's absence, Americans could probably relate to his yearning, having just ended a war where soldiers were separated from their families for long periods of time.

When viewed as a whole, the music in the Horner collection reveals several common themes. The most prominent of these are religion, death, and women. Seven different religious songs appear in the collection, and there are two copies of one of them for a total of eight songs. James Horner was active in St. Stephen's Episcopal Church in Oxford, once serving as a vestryman and senior warden. ${ }^{71}$ This devotion was likely shared by the rest of his family. Junius Horner became an Episcopalian minister. There are two types of religious sheet music that appear in the collection: pieces to be sung in church and pieces to be sung at home.

Two copies of "Grand Te Deum Laudamus" are present in the Horner collection. This piece was composed by Alvira Russell Hancock, wife of Civil War general Winfield Scott Hancock. Her name appears as Mrs. General W.S. Hancock on the sheet music. It is scored for SATB and organ and was intended for church performance. The piece includes several tempo and key changes as well as solos for each of the voices. The presence of the two copies in the collection suggest that it was used in church by two or more of the Horner family, and that perhaps they were members of a church choir. In both copies the first measure of the first Largo section is

\footnotetext{
${ }^{70}$ Charles Hamm, Yesterdays: Popular Song in America (New York: Norton, 1979), 265.

${ }^{71}$ Frederick Horner, The History of the Blair, Banister, and Braxton Families Before and After the Revolution with a Brief Sketch of Their Descendents (Philadelphia: J. B. Lippencott, 1898), 228.
} 
crossed out, indicating that a change was made in rehearsal of this piece. One of the copies has Nina Horner's name written on the cover page. The names "Effie," "Mr. Reed," "Miss Hyde," "Mr. Smart," "Mr. Hall," "Mrs. Park," and other illegible names are written above the solos lines throughout the piece, further supporting the idea that this piece was sung in a church choir. Nina had also written the word "all" in several places where she was to join in after the solos along with several penciled-in fortes. The other copy of "Grand Te Deum Laudamus" contains very few markings and no name, but simply the year 1898 written on the front cover.

Another piece intended for church is Albert W. Berg's “Te Deum.” This piece is part of a larger collection of church anthems and is part of a set of morning service music. It is scored for SATB in chorale style. The lines of text appear above and below the notation. This piece was likely used in the church choir or was meant to be sung from the congregation. It is much simpler than the "Grand Te Deum Laudamus" and contains no written notation from the owner. Another possibility is that this piece was sung at home by members of the family, with or without guests, as part of a family prayer time.

The other five pieces of sheet music in the Horner collection are written for piano and voice in the style typical of this collection. These are "Nearer My God to Thee," "Request," "Merry Robin," "Before," and "Sweet Evening Star". These pieces were probably added to the collection because their subject matter was considered appropriate for young women at the time, especially young women from a family as devout as the Horners seemed to be. Bailey describes a practice in which religious music was performed at home as part of social gatherings. The gatherings she described took the place of church on isolated antebellum plantations. Though congregating for worship was the intent of these meetings, Bailey explains that the social aspects 
of music-making were more important than the religious ones. ${ }^{72}$ It is difficult to say whether or not this practice made it into the Horner home. Since the Horners were active members of St. Stephen's Church in Oxford, it is unlikely that they hosted regular gatherings for the purpose of worship. What exists of their music collection also has few four-voice hymns that would have been typical for American hymns of the time. The number of religious pieces in the collection suggests that they were at least a favorite genre for the Horner women and perhaps one that they performed for others in their home.

Another theme that appears frequently in the sheet music from this collection is the subject of death, particularly the tragic deaths of young women. Five of the twenty-seven pieces of sheet music are concerned with this. They are: "She Sleeps Among the Daisies," "Tread Softly, the Angels Are Calling," "Looking Back," "When Stars Are in the Quiet Skies," and “The Ring My Mother Wore,” These songs mourn the loss of dearly loved women who often look as perfect and pure in death as they were in life. Finson explains in The Voices That Are Gone: Themes in Nineteenth-Century American Popular Song that death was a common theme in song because it was so familiar to people of the nineteenth century. ${ }^{73}$ Premature death was a tragedy that touched nearly everyone, and songs about death probably served as a means of coping with this hardship. ${ }^{74}$

\footnotetext{
${ }^{72}$ Candace Bailey, Music and the Southern Belle: From Accomplished Lady to Confederate Composer (Carbondale: Southern Illinois University Press, 2010), 49.

${ }^{73}$ Jon W. Finson, The Voices That Are Gone: Themes in Nineteenth-Century American Popular Song (New York: Oxford University Press, 1994), 83.

${ }^{74}$ See Charles O. Jackson, ed., Passing: The Vision of Death in America, Contributions in Family Studies vol. 2, (Westport, CT: Praeger, 1977).
} 
The Horner family experienced the death of two of their children at young ages. Their first son, James Pulliam died at age four. ${ }^{75}$ Because he was the first-born child and he died so young, the tragedy of his death did not directly affect his siblings, but the loss must have affected James and Sophronia, who then passed on these sentiments to the rest of their children. Also, if the parents were the ones purchasing the sheet music for their daughters, they may have been drawn to pieces about death. One of the daughters, Bettie Gertrude Horner, died at age eighteen in $1881 .^{76}$ As her death occurred ten years after the birth of the youngest Horner child, the loss must have been felt by everyone. The presence of several songs about young women dying suggests that the family perhaps found them comforting in their times of grief.

Two songs in particular, "She Sleeps Among the Daisies" and "Tread Softly, the Angels Are Calling," describe the deaths of young women and are present in the collection. "She Sleeps Among the Daisies," written by C.H. Webb and Lon Dinsmore is about the death of a female child who loved flowers in life and was aptly buried among the daisies in death. The song speaks of her youth and innocence referring to her as "our little Lillie" and "the little lisper" who "prayed to leave her happy home and slumber with the flowers." The cover of "Tread Softly, the Angels Are Calling” depicts a young woman on her death bed accompanied by her parents. Above her head, two angels are descending toward her to take her spirit away. The song describes just that and speaks of the pleasures of heaven that she will soon enjoy. Both songs were printed as part of the Boston Weekly Journal of Sheet Music and were distributed in the late 1890s, quite some time after Bettie Gertrude's death.

\footnotetext{
${ }^{75}$ Frederick Horner, 228.

76 “'Bettie Gertrude Horner,” Find a Grave, http://www.findagrave.com/cgibin/fg.cgi?page=gr\&GRid=28360865\&ref=acom (accessed 4 Nov. 2015).
} 
Women feature most prominently in the songs of the Horner collection. In addition to the songs about the death of women, there are also comic songs and love songs in which women take a leading role. There are several conflicting attitudes about women present in these songs, and given that this is a study of women, they are of special interest. While songs of women's deaths tend to portray them as innocent and childlike, comic songs point out their flaws and love songs their purity.

"Precious Treasure," another song from the Boston Weekly Journal of Sheet Music, provides interesting commentary on the courtship behaviors of men and women in the late nineteenth century. This song, written by Louis Weiler and Charles Felton Pidgin, was copyrighted by Pidgin in 1894 and published by F. Trifet in 1896. Pidgin, who was best known as a writer of alternate history and science fiction novels, is the lyricist. This is another of the comic songs in the Horner collection that concerns the social roles of men and women. The song depicts an overconfident and perhaps promiscuous man who seeks the affection of several different women, kisses them without permission, and is initially rejected. But the women eventually give in to his advances and return his affection. What is interesting about this is that the pure image of the nineteenth-century woman is retained, two of the women respond to the kiss by slapping him or boxing his ears, but in the end they are all fooled by his cunning scheme and come to love him anyway. On one hand, women are portrayed as ignorant and easily bent to men's wishes, they cannot seem to see this man as the scoundrel that he is and give in to his advances in the end. On the other hand, they are willing to resort to violence to who protect their dignities.

What the song says about men is equally as interesting. Here we have man who turns to trickery to obtain the affections of three different women. Though he fails at first with two of 
them, in the end he is rewarded by earning the name "Turtle Dove" from them. The woman in the second verse comes to love him because of an act of chivalry when she falls into some body of water and he jumps in after her. At the beginning of the verse, he explains that he had been smoking and drinking prior to the incident, suggesting that this was perhaps the reason for his actions rather than actual chivalry. In the end, the man in the song is celebrated for his ability to convince women to accept him despite his character flaws, and the women come out looking unable to defend themselves from his deceit.

"The Whistling Wife," the song after which this study is named, is another comic song that reveals contemporary attitudes about women, even if only done in jest. This song was written by Harry Randall and published by F. Trifet in 1898. William Thomas "Harry" Randall (1857-1932) was a British Vaudeville actor who wrote at least a few comic songs concerning women. ${ }^{77}$ Several songs were published in the 1890 s and bear his name as either the composer, indicate that he sang them, or both. The songs were published in both the United States (New York City and Boston) and in London. All of these songs are comic in nature and tend to point out domestic and social problems between men and women. Though Randall was British, his songs gained popularity in the United States. Though their publication was not as widespread in the United States as in Britain, they caught the attention of several American publishers who printed and sold them to the American public.

The sheet music for "The Whistling Wife" gives no indication of a lyricist, so it is likely that he wrote the lyrics himself. The lyrics feature a male speaker who is frustrated with his wife's whistling habit:

\footnotetext{
77 “Harry Beard Collection," Victoria and Albert Museum, http://collections.vam.ac.uk/item/O1157185/harrybeard-collection-sheet-music-randall-harry/ (accessed 4 Nov. 2015).
} 
You've heard about the latest fad

That fills us with amaze

I mean that silly fashion, called

The female whistling craze

My wife is fairly on the job

Although it's so absurd

And all day long to my dismay

She whistles like a bird

She never calls me by my name

But treats me like a log

For now she always whistles me

As if I were a dog

Last Sunday night we went to church

And I with shame turned red

For when the people sang the hymns

She whistled 'em instead!

She's known to all the "pubs" around

She wets her whistle now

And if I want my meals at home

It don't come off somehow

I have to whistle for my grub

And chirrup for a sip

And they say we're the lov'liest pair

That ever "cocked a lip"!

You should hear her whistling

Drives me mad with whistling

She starts it in the ev'ning

And don't leave off till dawn

You should hear her whistling

Different kinds of whistling

She whistles "Yankee Doodle"

And the "Dead March of Saul"

There are several points to be taken from this text concerning women's roles in the late nineteenth century. Though we can assume Randall's song speaks about women's roles in his home country, the fact that the sheet music was printed in the United States suggests that Americans found the humor successful as well. One concern that stands out in this text is that it was undesirable to have a wife who whistled. The speaker makes this clear several times by 
saying the whistling is a "silly fashion," "absurd," and causes him shame, even driving him mad. This "female whistling craze" seems to have been unacceptable in polite society. Another concern is that the whistling was interfering with the speaker's wife's ability to perform her wifely tasks. He complains that she no longer makes meals for him and that she does not call him by his name, but whistles for him. Perhaps the most interesting connection this song makes is that between having a whistling habit and drinking. The speaker implies that that her whistling habit has led her to visit the pubs and "wet her whistle." One reason for this may be that whistling was seen as acceptable male habit, so a whistling

What does all of this say about nineteenth-century American women? As I explained earlier, the fact that this song was printed and purchased in the United States suggests Americans were able to relate to its humor. The presence of this song in a southern sheet music collection indicates to me that the owner of the collections also viewed whistling as an impolite habit for women in her own social context. As members of the elite white class, the Horner daughters would have strived to maintain their elite image with by behaving as well-mannered and sophisticated ladies, a practice which would not have included whistling in the late nineteenth century.

Another piece of music that is of special interest in this collection is J.P. Tingen's "Free Coinage of Gold and Silver at 16 to 1 .” This song very explicitly communicates political concerns over money in the 1890s. The issue stemmed from the Coinage Act of 1873, when silver was demonetized. Prior to this act, the United States had a bimetallist monetary system with both gold and silver backing the nation's currency. In 1878, silver was restored as currency with the Bland-Allison Act and the U.S. Treasury was required to coin between two and four million dollars in silver each month. Nearly a decade later, farmers called for more silver after 
farm and land prices dropped during a recession. The government responded with yet another increase in silver coinage with the Sherman Silver Purchase Act of 1890. Many Americans, including farmers in the Midwest and South and silver miners in the West, thought a return to free coinage of silver would benefit the common American. Those against the act complained that it benefited the banks and railroads while exacerbating the rest of the nation's financial problems. $^{78}$

The composer of this song, J.P. (Joseph Pherrell) Tingen, is not especially well-known in the field of songwriting, but he is perhaps best known as the composer of "In the Sweet Bye and Bye." Tingen was born in Person County, North Carolina and served in the $24^{\text {th }}$ N.C. Regiment during the war as the regiment's bandmaster. After the war he served as a Justice of the Peace and a Postmaster. He seems to have resided in Person County for his entire life as a musician, songwriter, and farmer. He is also credited with having written "God Be With You" and "Till We Meet Again.",79

The cover page of the sheet music includes a caption that says: "This piece of music and poetry, is dedicated to the people of the United States by the author, in aid of the restoration of silver to its original dignity as a standard of money with gold, to be coined at the ratio of 16 to 1." The text of the song is as follows:

\footnotetext{
${ }^{78}$ Alan Gevinson, "Silverites, Populists, and the Movement for Free Silver," TeachingHistory.org, National History Education Clearinghouse, http://teachinghistory.org/history-content/ask-a-historian/25222 (accessed 4 Nov. 2015). 79 “Joseph Pherrell Tingen,” Find a Grave, http://www.findagrave.com/cgi-bin/fg.cgi?page=gr\&GRid=79029236 (accessed 4 Nov. 2015).
} 
The South is for Silver, the North is for Gold, It will be the plan to show at the polls That Silver is needed together with Gold, To bring to the country that needed repose. When Silver is restored all over the land, Then we will be happy in finances grand, And stand by our banner for Silver and Gold At sixteen to one as the fathers of old.

Sixteen to One Coinage so we have been told Was fixed by the fathers in days of old, But now Gold Bugs have invented a plan, That surely will crush out the poor of the land.

If the people would be free from British Gold rule, Then they must be zealous and not be their tools, To vote the Gold Standard and make us all slaves, To do as they bid us and call us but knaves.

The farmers are toiling much harder today, And getting less pay so all of them say, The reason is plain and so we all do find That Silver is nulled and not coined from the mines. The monopoly and trusts of every name Has joined in to blight us, and this is a shame, That they should so fleece us who toil for our bread, Their doings will surely come down on their heads.

Among the worst combines that ever has been, Is formed on Tobacco, Whiskey and Gin, Except the Gold Standard for that is the worst That causes the rich and the poor all to burst. When the Silver is restored all over the land, Then we will be happy in finances grand, And stand by our banner for Silver and Gold At sixteen to one as the fathers of old.

Come all ye true patriots of every name, And join in the fight our interest the same, And vote for Free Coinage of Silver and Gold, At Sixteen to One as the fathers of old. Let the people all unite in union so sweet, And then what a blessing to see and to greet Each other with kindness and friendship so good, And joy in the right for which we have stood. 
The people united, the victory is won, Then we will be happy, bright as the sun, And cheerfully go forward in business so gay, And trust in the Lord for the bright coming day. When the Silver is restored all over the land, Then we will be happy in finances grand, And stand by our banner for Silver and Gold, And say to Great Britain, we're free from your toll.

Unite ye people of the land, And vote for Silver to a man, And then we'll show to all the rest, Both Gold and Silver too, is the best. Hurrah for Silver in the land, Unite in one true, noble band, And say to all the world beside,

In Gold and Silver too, we confide.

This text is very explicit in its political aims. Several times it calls for the vote for silver, and the language attempts to persuade listeners by comparing the gold standard to being slaves to Britain. This piece of sheet music serves primarily as a means of promoting a political idea with the text. The Horner's place in their society as a prominent southern family and the presence of this song in their collection suggests that they may have held the views about free coinage expressed in the text.

The music itself is of little importance, though it is interesting to note the hymn style in which it was written. Perhaps this is because this was the style the composer knew how to write in, but one cannot help but wonder if writing it in the style of church music was done with the intention of appealing to the audience's sense of religious duty. It is also important to note that the music is written in shape note notation, making it accessible to those without much musical training. This song was self-published by J.P. Tingen in his hometown of Ai, Person County, North Carolina. Another of Tingen's songs in this collection, "Merry Robin," which is also written in shape-notes, was published the same way. The proximity of Oxford, where the 
Horners lived, and Ai suggests that both pieces were not widely distributed. Their presence in the Horner collection is significant because they help situate the collection in its time and place.

Several conclusions can be drawn from an examination of the contents of the Horner volume. I have already discussed the family's seeming preference for religious music, suggested that they many have found comfort with the songs about death, and participated in the belief of common contemporary social and political ideas with their acceptance of comic and political songs. There are also several other broad conclusions to be drawn from the collection as a whole that offer insight into the lives of the Horner women.

One reason the Horner volume stands out from others in the Nineteenth-Century American Sheet Music Collection is that, except for one piece of piano solo sheet music and church music, it is comprised entirely of songs for voice and piano. This suggests that the Horner daughters did more singing than piano-playing and perhaps did not have much formal musical training. Several census records list the occupation of some of the daughters as "at school." Though this could mean they were being educated at home, it is also possible that they were attended a boarding or day school where music might have been one of the subjects. Based on some of the markings in Nina Horner's "Grand Te Deum Laudamus" part, she was not especially adept at music-making. For instance, her marking of who was singing each solo suggest that she had to write the names in to remind herself wither not to sing there or to keep her place. If the date written on the other copy of the piece is to be believed, Nina would have been thirty years old at the time, so her markings cannot be explained by youthful inexperience. The one piece of piano sheet music, “The Flower of Andalusia” (pub. 1827) has the earliest publication date of any of the pieces in the collection. It is possible that this piece was passed down to the Horner 
daughters from their mother, who might have had a better opportunity to learn how to play the piano as the daughter of Portius Moore, a prominent North Carolina planter and slave owner. ${ }^{80}$

What is perhaps most important about the Horner collection is what it says about the time in which the Horners lived. The collection's existence indicates that the family tried to cling to the social construct that was feminine music-making. Though the depth of the Horner daughters' musical education is unclear, an effort was made to provide them with suitable music to sing and play. As Laura F. Edwards discussed in her study, the Horner family was by no means wealthy after the Civil War, but they did maintain a certain social standing that marked them as part of the uppercrust in their community. The size of the collection (it is quite small compared to others in the Nineteenth-Century American Sheet Music Collection) and the tenuous grasp of musical concepts shown by Nina Horner's markings indicate that the family did not have the means to provide their daughters with the same kind of education that someone from their mother's generation might have enjoyed. An understanding of this sheet music collection in its time and place reveals a truth that was widespread in the South after the war: that the elite classes tried to preserve the aspects of their lives that set them apart from the other classes before the war, but not without great difficulty due to the drastic economic and social changes. ${ }^{81}$

\footnotetext{
80 “Dr. Portius Moore," Find a Grave, http://www.findagrave.com/cgi-bin/fg.cgi?page=gr\&GRid=38519170 (accessed 4 Nov. 2015).

${ }^{81}$ Edwards, 116.
} 


\section{Chapter 3 \\ Old Series LXXXVIII}

While the Horner family's sheet music collection seems to tell the story of a prominent southern family struggling to maintain their social standing after the Civil War, another collection, Old Series LXXXVIII, paints a picture of a northern family with an entirely different set of concerns. The pieces in this collection have publication dates in the 1880s and 1890s, so it is roughly contemporary with the Horner volume, but its content differs greatly. This volume is much larger, containing more songs and piano music than the Horner volume, and the themes and topics covered in the songs suggest the owner had an entirely different taste in music than the Horner daughters.

This collection was owned by a woman named Florence Turner Pond. Her name can be found handwritten on several of the collection's pieces in a variety of ways. It also appears as Florence T. Pond, Miss F. Pond, and F.T.P. The use of the title "Miss" indicates that Pond is her birth name, and this collection was made prior to any marriage she might have had. Two other names that appear are S. J. Brandy and R. T. Turner. "Turner" seems to have been a family name that was given to Florence as a middle name. It is possible that R. T. Turner was Florence's mother and the piece that bears her name was passed on to her daughter, but since there is no publication date, it is difficult to tell. According to census records, Florence Pond was born around 1871 in New Jersey, where she seems to have spent all of her short life. ${ }^{82}$ I could not locate records containing information about Florence's mother aside from the 1880 census, which states Florence's mother's birthplace as South Carolina. She is not named as a member of the household in this census and Florence's father is listed as unmarried. He married Annie

\footnotetext{
${ }^{82} 1880$ U.S. Census, Union County, New Jersey, population schedule, Plainfield, p. 475B, dwelling 308, family 321, Florence Pond; digital image, Ancestry.com, accessed 4 Nov. 2015, http://ancestry.com.
} 
Boorman in 1894, two years before Florence's death, when Florence was in her early twenties. ${ }^{83}$ Florence lived with her father and his new wife after their marriage and probably until her death in $1896 .{ }^{84}$ She died around the age of twenty-five, having never married and leaving her estate to her father. ${ }^{85}$

Florence and her father lived in Plainfield, New Jersey with her grandparents when she was nine, and, based on the presence of a Plainfield music dealer's stamp on a piece in her collection, she either lived there or visited it often through adolescence. Her father was employed as a clerk in 1880 but was sick or disabled and unable to carry out his occupational duties at the time, which perhaps explains why he and Florence lived with his parents. The nature of his illness is not specified. A document from the New Jersey Union County Orphan's Court, signed on June 27, 1890, petitioned for Charles F. Pond to be appointed as her guardian, indicating that, though she seems to have lived with her father before that time, her legal guardianship belonged to someone else, perhaps her mother. The document specifies that her property, valued at fifteen hundred dollars, should go to Charles. ${ }^{86}$

Though more exact details of Florence's childhood cannot be known from the available records, an impression of the kind of upbringing she had can be inferred. Florence spent much

\footnotetext{
${ }^{83} 1880$ U.S. Census, Union County, New Jersey, population schedule, Plainfield, p. 15B, dwelling 302, family 338, Charles F. Pond; digital image, Ancestry.com, accessed 4 Nov. 2015, http://ancestry.com.

${ }^{84} 1895$ State Census, New Jersey, Union County, population schedule, Plainfield, p.124, dwelling 709, family 827, Charles F. Pond; digital image, Ancestry.com, accessed 4 Nov. 2015, http://ancestry.com.

${ }^{85}$ New Jersey Surrogate's Court (Somerset County), Oct. 5, 1890, Florence T. Pond, Probate Records, 1785-1924. Ancestry.com, accessed 4 Nov. 2015, http://ancestry.com

${ }^{86}$ New Jersey Surrogate's Court (Union County), June 27, 1890, Florence T. Pond Guardianship, Probate Records, 1854-1931. Ancestry.com, accessed 4 Nov. 2015, http://ancestry.com.
} 
of, if not all of, her childhood and early adulthood in New Jersey. Her parents were not married for most of her life, if any of it. Records do not indicate the existence of any siblings from her father's side of the family, so she was likely an only child. Though her family's financial circumstances are not known, her music collection indicates that they were reasonably comfortable. The size and content of her collection, contrasted with the Horner collection, sheds light on some fundamental differences between young women of the postbellum North and South in regard to the role music played in their lives.

It was likely that she received a more thorough musical education than the Horner daughters. The collection is larger than the Horner collection and roughly half of it is piano music. This indicates that Florence was reasonably skilled at playing the piano, at least enough to collect twenty pieces of piano music. Many of the piano pieces are dance or march pieces typical of the nineteenth-century southern belle collection. ${ }^{87}$ Some of the pieces bear names in foreign languages, especially German, and some appear to have been published in foreign countries. One possible interpretation of the presence of these songs in the collection is that she was wealthy enough to afford to order these pieces, or knew someone who had the means to travel and bring them back for her. One song bears the stamp of the William A. Pond Music Store and another, Hitchcock's Music Store, both in New York City. ${ }^{88}$ Also noteworthy is that Florence seems to have been an only child, where the Horner family had ten children. It is possible that this arrangement was to Florence's benefit. She did not have to share her father's resources with

\footnotetext{
${ }^{87}$ See Candace Bailey, Music and the Southern Belle: From Accomplished Lady to Confederate Composer (Carbondale: Southern Illinois University Press, 2010), 93.

${ }^{88}$ I searched for a family connection between Florence's family and the music publishing business started by Sylvanus Pond and continued by his son William, originally Firth, Pond and Company, but there did not seem to be a direct link between the two families.
} 
siblings and may have had additional support from her grandparents, with whom she lived, at least for a short while. ${ }^{89}$

The collection divides neatly into three groups: coon songs, other songs (mostly about love and courtship, but with a few others about home, death, nostalgia, etc.), and piano music. This chapter will focus on the content of the songs and what they say about nineteenth-century values concerning race, women, and courtship, as well as Florence Pond's taste in music and the ideas she would have been exposed to through these songs.

Most of the songs in this collection can be traced back to a Tin Pan Alley publisher or a publisher of similar types of songs in different cities, particularly Boston. For the most part, these songs fit into two categories: those containing racial elements (coon songs) and those about courtship and love. It is worth noting that these were two of the most popular kinds of songs in the late nineteenth century. ${ }^{90}$ The presence of these songs in the Pond collection seems to indicate that this collection is a good representation of musical interests among the white middle class at this time in American history. The coon songs, though their depiction of nineteenthcentury black Americans is deplorable, represent a trend in American culture marked by both an attitude of white superiority and a fascination with blackness. ${ }^{91}$ These attitudes are made clear in the twelve coon songs present in the Pond collection.

The coon songs display the racial stereotypes typical of the era from which they come in several ways. The lyrics are written in what was meant to imitate the plantation slave dialect and

\footnotetext{
${ }^{89} 1880$ U.S. Census, Union County, New Jersey, population schedule, Plainfield, p. 475B, dwelling 308, family 321, Florence Pond; digital image, Ancestry.com, accessed 4 Nov. 2015, http://ancestry.com.

${ }^{90}$ Charles Hamm, Yesterdays: Popular Song in America (New York: Norton, 1979), 253.

${ }^{91}$ Jon W. Finson, The Voices That Are Gone: Themes in Nineteenth-Century American Popular Song (New York: Oxford University Press, 1994), 200.
} 
demonstrate stereotypes of black inferiority. The cover images often support these stereotypes by illustrating exaggerated bodily features unfairly associated with African Americans and generally presenting them in crude and primitive ways. Some of these songs were popularized my minstrel shows and bear the names of the minstrel troupes on the front covers. Others were written independently and printed by the publishers of the booming music publishing business of the 1880s and 1890s, including Tin Pan Alley publisher T.B. Harms, and White, Smith \& Co in Boston. $^{92}$

Five of these songs were written by Monroe H. Rosenfeld (1861-1918), a prolific songwriter during the 1880s and 1890s who composed for sheet music publishers in Boston and New York. He is said to have coined the term "Tin Pan Alley" while he worked as a journalist for the New York Herald. He is credited with have written over a thousand songs under his own name and pseudonyms F. Heiser and F. Belasco. Rosenfeld was known for his ability to adapt to the public interest with his songs and there are marked changes in the content of his works over the two decades where he was most active. Of his early successful works, many of them appear to have been coon songs, written between about 1881 and 1885 . By the end of the 1880 s, he was writing sentimental songs and dance songs to accommodate consumer interests. His early successful songs were published in Boston by several publishers, but most of his songwriting career took place in New York where his songs were picked up by the Tin Pan Alley publishers. $^{93}$

\footnotetext{
${ }^{92}$ See Lynn Abbott and Doug Seroff, Ragged but Right: Black Traveling Shows, "Coon Songs," and the Dark pathway to Blues and Jazz, (Jackson: University Press of Mississippi, 2009). 
The songs in the Pond collection are from his coon song days. There are five of them, all published in the early 1880s in Boston. Their titles are: "Come Along Sinners," "Hulda's Baby," “Climbing Up de Golden Stairs," "I'se Gwine to Weep No More," and "Hie Away Ole Satan." There are several common themes in these songs; the lyrics are written in the stereotypical plantation slave dialect, they include crude racial imagery on the front covers, and they exhibit derogatory racial stereotypes with the language and attitudes present in the lyrics. According to a notation on the front cover of "Hulda's Baby," Rosenfeld drew the illustration for the front cover himself. Rosenfeld's other songs feature strikingly similar images on their front covers, indicating that these were drawn by him as well. The front covers of three of the songs feature drawings of a black baby with an exaggeratedly large head and two teeth on the lower jaw holding either a switch blade or a banjo. In one of these, the baby is preparing to decapitate a chicken.

The images raise several questions about the underlying prejudices that created them. One possible interpretation is that all free blacks, even the infants, were dangerous and crude enough to be carrying weapons at all times. Another interpretation is that free blacks were superstitious enough to try to defend themselves from Satan with a weapon, which seems to be the case in image present on one of the song's cover pages, "Hie Away Old Satan," in which a black woman and her infant child (holding a switch blade) look on in fear as they are approached by a man with a horn. Interestingly, this man is white.

These images paint a vivid picture of the prejudice held against free blacks in the postbellum South. They were thought to be uneducated and superstitious, crude, violent, and were depicted with exaggerated and cartoonish physical features. A question that this raises is: why was it necessary to include these images on the front of sheet music? One possible (and 
probable) answer was that it was done in order to sell more copies. These songs were marketed to a white audience who might have found the cover images to be comical. Another possible reason is that they were made to appeal to the white population's sense of superiority over the newly freed black population. These images could have served to keep the black community in a place of inferiority during a time when it was trying to redefine itself after the Emancipation. These songs probably sold many copies due to the popularity of sheet music at that time, so these images would have been disseminated widely.

Rosenfeld's “Come Along Sinners," published in 1881 by White, Smith \& Co. has several notable characteristics. Rosenfeld wrote both the lyrics and music and dedicated the song to "Lotta," perhaps a performer of such kinds of songs. The image on the front cover of the sheet music shows a black man being picked up by a large hand, perhaps the hand of death, and carried upward while four onlookers watch in horror. The man has a razor blade in his back pocket and the two of the male onlookers seem to have discarded theirs on the ground next to them. In the background appears a small shack and in the distance what looks like a plantation house. The most disturbing aspect of this image is the looks of terror on the faces. All four faces have mouths opened wide to reveal teeth that are large and exaggeratedly white, perhaps playing to contemporary stereotypes. 


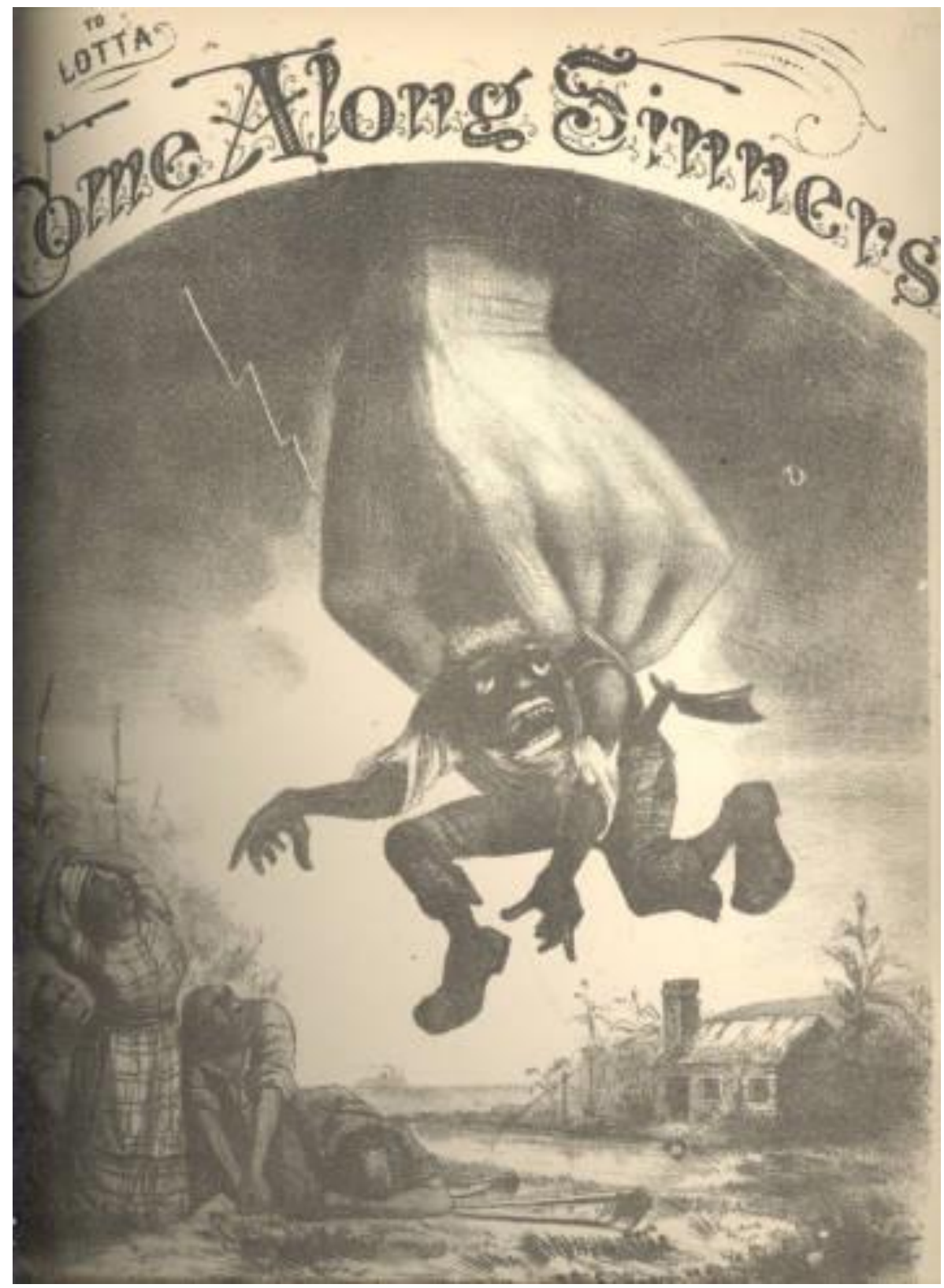

"Come Along Sinners"

Source: Nineteenth-Century American Sheet Music Collection, Music Library, University of North Carolina at Chapel Hill, http://dc.lib.unc.edu/cdm/compoundobject/collection/sheetmusic/id/34456/rec/5

The lyrics describe the impending doom of the coming of death. They are written with spellings typical of coon songs and meant to imitate the plantation slave dialect, included spelled-out mispronunciations, misused words, incorrectly used verbs, other dialectical 
differences that draw attention to the plantation slave's lack of education. The lyrics include a warning to "darkies" trying to enter the gates of Heaven that "dat am de time you'll get left out sinner, dat am de time you'll get left out late, dat am de time you will get no dinner, and be lock'd from de golden gate." This perhaps indicates that blacks were seen as especially devious, and the song warns that trying to sneak into Heaven will get them locked out for good. The final verse explains that they will be let in only when "you'se a hearin de fire a sizzin," or when, as it says earlier in the verse, when Satan is coming. It is also important to note that the melody of this song does not match the tone of the lyrics at all. The melody is rather fast and chipper in the key of F major, while the lyrics speak of death and sinners, indicating that the song's speaker does not take the matter seriously.

"Hulda's Baby," published by Louis P. Goullaud in Boston, is the companion piece to "Come Along Sinners." It is an upbeat song in G major, containing the same kinds of rhythmic gestures found in "Come Along Sinners," namely the dotted-eighth-sixteenth rhythm that seems to create a jaunty? momentum. It also uses the plantation dialect. The subject matter, however, is quite different. The lyrics speak of Hulda, presumably a black woman, who recently had a baby, but nobody knows from where it came. This causes some discontent as “dar's a row in de camp tonight on account of Hulda's baby." Though the language is not explicit about what is going on in this song, one has to wonder if it intends to portray black women as promiscuous and black men as territorial. The fight that arises at the seemingly unexpected birth of a baby suggests this. Another attitude present in the song is that blacks were superstitious. The second verse claims that the child was obtained from a hickory tree, and the third verse, while it claims this is unlikely, seems to consider it a possibility. 
The cover of "Hulda's Baby" features a drawing of the black baby seen on a few of the other songs. The baby is holding a chicken by the neck in one hand and a razor blade in the other, perhaps preparing to cut off the chicken's head. This image has little to do with the actual song, the only connection being that both the cover and the song feature a baby. The use of this image was probably to sell copies of the sheet music by presenting an image of the stereotypes commonly found on sheet music of this type. The cover also includes a dedication to Charles $\mathrm{H}$. Yale. This probably refers to the New York theatre producer with which Rosenfeld might have collaborated. It also includes another pseudonym for the composer, Tobias Toothpick, though Rosenfeld's actual name appears on the first page of music. The name "Tobias Toothpick" also appeared in an issue of Puck, a late nineteenth-century journal. A poem by Tobias Toothpick appears in an issue from January 3, $1883 .{ }^{94}$ Since Rosenfeld was involved in the New York journalistic circuit and wrote the lyrics for his own songs, it is likely that these two are one and the same.

\footnotetext{
${ }^{94}$ Puck, no. 12 (1883), 283.
} 


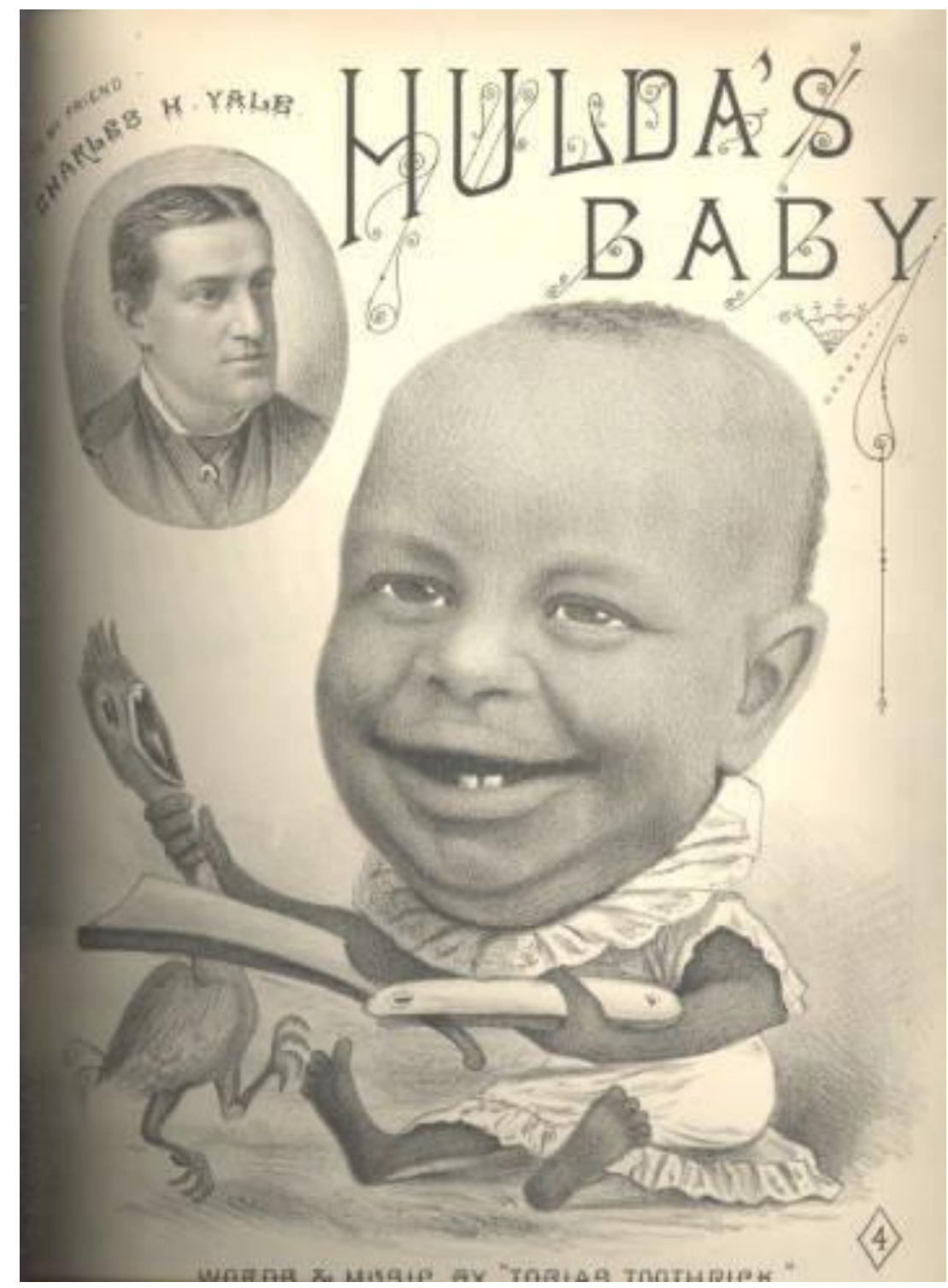

"Hulda's Baby"

Source: Nineteenth-Century American Sheet Music Collection, Music Library, University of North Carolina at Chapel Hill, http://dc.lib.unc.edu/cdm/compoundobject/collection/sheetmusic/id/34482/rec/1

In general, the Pond collection contains a lot of music that represents the late-nineteenth century fascination with and unfair depiction of African Americans. In addition to the twelve coon songs, there is a piano piece called "Following Up the Band: An African Sonata for Piano" by William A. Pratt. This piece was published in 1900 by K. Dehnhoff in New York, four years after Florence's death. It is possible that this piece was added to the collection by the person who 
appropriated the collection after her death. It represents the Tin Pan Alley version of "ragtime," that is, syncopated march music. The cover identifies the piece as a "cakewalk" and "characteristic two-step march." The cover also features an illustration of an African-American marching band marching past as an African-American woman stands by. All of the people depicted on the cover have strikingly similar and exaggerated facial features, much like those found in the cover illustrations of some of the coon songs.

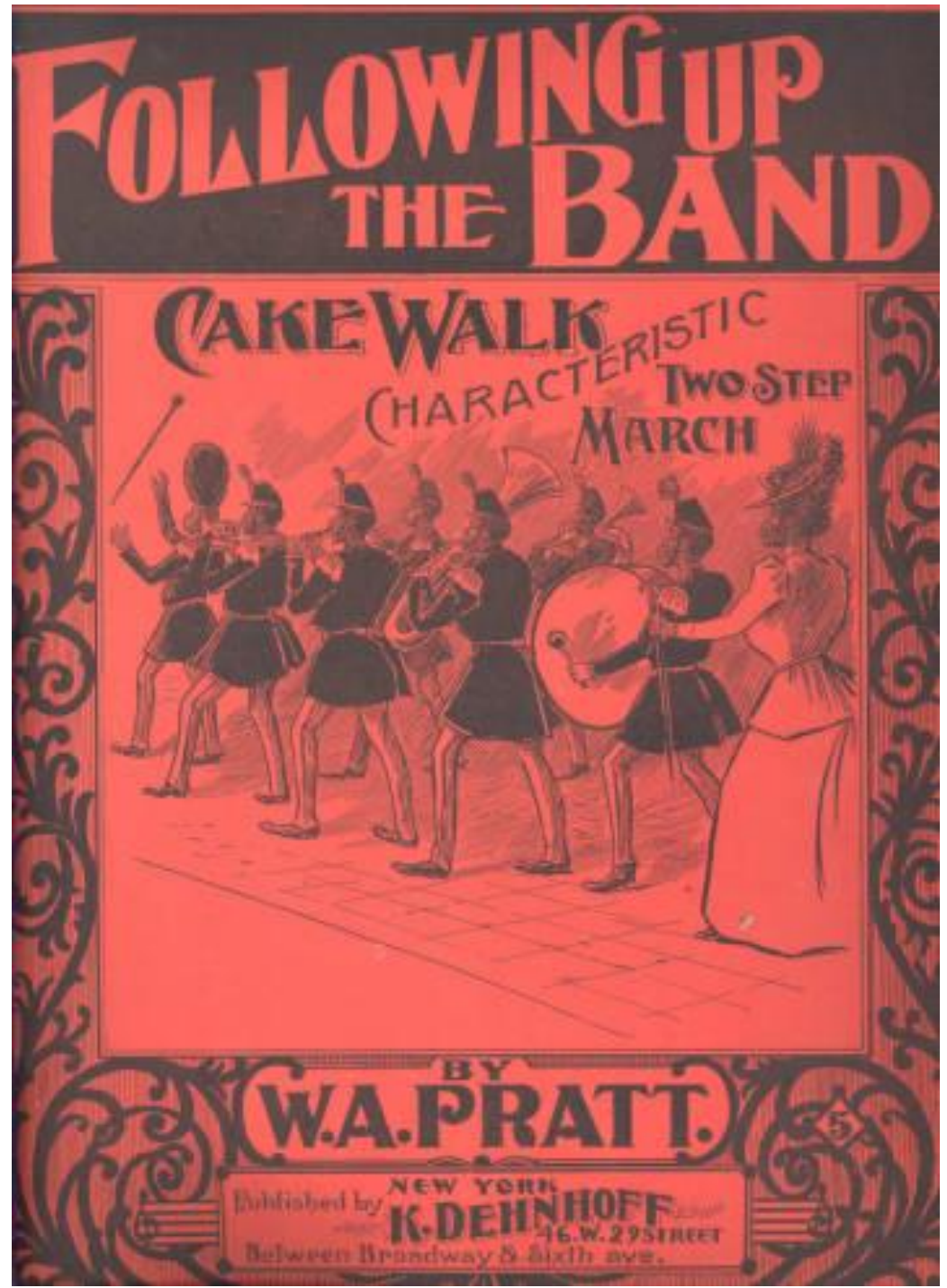

"Following Up the Band"

Source: Nineteenth-Century American Sheet Music Collection, Music Library, University of North Carolina at Chapel Hill, http://dc.lib.unc.edu/cdm/compoundobject/collection/sheetmusic/id/35013/rec/1 
Other than a few instances of syncopation in the melody, the music itself lacks any real connections to African or African-American musical traditions. It seems the subtitle, "African Sonata," was intended merely to sell copies. This piece, and this collection in general, reveals a trend in popular sheet music at the end of the nineteenth century. Sheet music depicting black stereotypes, even when the actual music has little to do with African Americans, was highly marketable material. The successful sale of these kinds of pieces reveals the public acceptance of these stereotypes. The presence of this type of music in this young woman's collection suggests that the stereotypes were so ubiquitous that singing songs about them was considered an acceptable pastime for proper young ladies.

Another prevailing topic in the songs of the Pond collection is love and courtship. Several of the songs celebrate the sweetness and purity of a maiden in love, while others point out the darker side of love with descriptions of unrequited love, deception in love, and the death of a loved one. Songs of this type were typical in the nineteenth century and stem from a tradition in popular song that began in the eighteenth century. Finson explains that love and courtship became popular topics of song in the late eighteenth century as American society's attitudes changed concerning marriage. As fewer marriages were arranged and more couples had to engage in courtship to seek their spouses, ideas about proper behavior and etiquette for both men and women emerged. ${ }^{95}$ These attitudes continued to present themselves in popular song into the nineteenth century and up to the present, changing to suit the values of the time in which the songs were written.

The love songs of the 1880 s and 1890 s present in the Pond collection reveal contemporary attitudes on the subject. There are several songs in the collection that are notable

\footnotetext{
${ }^{95}$ Finson, 4.
} 
in this way. One of them, "I Called Her My Pansy Blossom," is one that speaks of the virtues of modesty and purity in maidenhood. Written by J. Albert Snow and George Russell Jackson, and published by W.A. Evans in Boston in 1883, this song celebrates the image of unmarried young women as sweet and innocent. The song speaks of a "radiant maiden" who "beam[s] with modesty" and is likened to a pansy blossom because of this. The song goes on with similar praises to this vision of womanly perfection. Though the song does speak of her beauty, the key attribute that it seems to promote is her modesty. The word is used several times in the song. According to the lyrics, her face beams with it. We do not learn much else about this woman other than this fact, indicating that this is all that matters. No doubt this woman would have been a most appealing spouse.

Two other songs in the Pond collection celebrate the purity of maidenhood. "Sweet Marie" written by Raymon Moore and Cy Warman and published in 1893 by Manhattan Music Publishing Co. expresses sentiments similar to those found in "I Called Her My Pansy Blossom." The young woman about which the song speaks, Sweet Marie, is described as being fair of face and pure of soul, and her adorers "falter at [her] feet." This sentiment is also present in "Norah Clare" written by Samuel Bradbury and published in 1884 by Hitchcock Publishing House in New York. In addition to speaking of Norah Clare's beauty, this song emphasizes her virtue. When asked for her hand in marriage she blushes and says "I'll be as true as stars that shine." Not is celebrated not only for being a pretty young woman, but also for her demeanor. She is flattered to the point of blushing at a marriage proposal. Also of interest is that she answers the proposal with a promise to be faithful in marriage, assuring her partner of her virtuous ways, when a simple "yes" would have sufficed. 
Because these songs were meant to be collected and sung by young women, their content must have been instructive to young Florence Pond. Her ownership of this and similar songs indicates that she either found them appealing, or was instructed that they were proper music for a young lady to play. Finson describes this image of the "angelic" woman in popular songs after the war. He says "songs about fidelity suggest that even when women play an active part in courtship, their roles afterward remain strictly defined: they must marry and stay in the home where men will adore them as shining examples of purity. ${ }^{96}$ As rules regarding courtship began to allow for greater participation from the female party, this attitude might have been especially important in keeping women in their domestic place. Men, on the other hand, are treated with more flexibility in popular song. While in some songs, the last three of this discussion for example, the male speaker is an adoring observer of the female subject with, as far as one can tell, honorable intentions, in other songs, men are portrayed as dubious, dishonorable, or immoral. Finson uses the words "demonic" and "habitually evil.".97 Songs of this type, such as (the one in the Horner collection) and to some extent "The Man Who Broke the Bank at Monte Carlo in the Pond collection, make nineteenth-century women seem morally superior by comparison. While the main point of "Monte Carlo" is to point out the absurdity of an ungentlemanly man who gambled his way to becoming a "gentleman," the third verse makes an additional comment about love. After making his fortune, he goes to Paris in order to find a French woman, who "with twenty tongues, she swears that she'll be true." The man in this song not only makes a fortune in a less-than-reputable way, but he also earns the love and fidelity of a

\footnotetext{
${ }^{96}$ Ibid., 52.

${ }^{97}$ Ibid., 54.
} 
woman that, based on the general tone of the song, he only gained because he was lucky, not because he was deserving.

"We Smile and Speak as We Pass By" is another song in the Pond collection that comments on behaviors of courtship. Written by J. Albert Snow and George A. Russell, this song is the companion piece to "We Never Speak as We Pass By," a set of piano variations by Snow, which is not found in the Pond Collection. A copy does exist in the collection of notated music at the Library of Congress. Both were published by W.A. Evans and Bro. in 1883. The song and the piano variations consist of essentially the same musical material, so one must be an arrangement of the other. The song speaks of a young woman, beautiful and possessing all of the social graces desirable in a nineteenth-century woman, whom the speaker hopes to make his wife despite her seeming lack of interest in him. His hope comes from her polite acknowledgement of his existence when they meet in public. He notes that she will converse with him at parties and that they, as the song title suggests, "smile and speak as [they] pass by," which is enough to assure him that she is interested in him. This raises an interesting question about women's roles in courtship in the nineteenth century. By this time it was socially acceptable for women to take a more active role in courtship than ever before, but their participation was still limited, and songs such as this one suggest that this limited participation was more desirable. The woman in the song is celebrated for her subtlety in the courtship rituals. This characteristic seems to make her even more attractive to the speaker, who interprets her behavior, which is not much more than an acknowledgement of his existence, as proof that she will become his wife.

Not all of the songs about love and courtship speak of women as examples of modesty and grace. Some of them speak of a darker and more painful side of love than the joy and innocence associated with courtship. "When We Two Parted," written by Richard Stahl and set 
to a poem by Lord Byron, tells of a union gone terribly wrong. The speaker's gender is not identified as he or she explains the pain and bitterness he or she feels at the memory of having been in love. The text of Lord Byron's poem, and that found in the song, is as follows:

When we two parted

In silence and tears, Half broken-hearted

To sever for years,

Pale grew thy cheek and cold, Colder thy kiss;

Truly that hour foretold Sorrow to this.

The dew of the morning Sunk chill on my brow-It felt like the warning

Of what I feel now.

Thy vows are all broken,

And light is thy fame;

I hear thy name spoken, And share in its shame.

They name thee before me, A knell to mine ear;

A shudder comes o'er me-Why wert thou so dear?

They know not I knew thee,

Who knew thee too well--

Long, long shall I rue thee, Too deeply to tell.

In secret we met--

In silence I grieve,

That thy heart could forget,

Thy spirit deceive.

If I should meet thee

After long years,

How should I greet thee?--

With silence and tears.

This is a more powerful text than seen anywhere else in the Pond collection. This is due in part to the fact that it was written by a skilled poet. The text reflects real emotions, whereas 
many of the popular songs written in the last two decades of the nineteenth century have simple and sentimental or comical texts designed to sell copies of sheet music. Songs such as this one, which use a poetic text must have had some appeal, however, as they do appear with some frequency in nineteenth-century music collections. Young women who attended boarding or day schools, or who were taught at home, were likely exposed to poetry as part of their education, and may very well have been familiar with the works of Lord Byron as part of their study of literature. ${ }^{98}$ Whether or not this was the composer's intention in selecting this particular text for his song is unknown, but in doing so, he introduced darkness to an area of popular song that was otherwise mostly light of topic.

Another song in the collection to set poetry to music is "The Broken Pitcher." The music was written by Henry Pontet and the text is taken from the Nemo, a work of poetry by Ulrich von Hutten from the sixteenth century. The front cover lists the lyricist as "Nemo," though this name refers to where the text was taken from rather than its author. The text of "The Broken Pitcher" is as follows:

Trip, trip, over the grass, Merrily went a laughing lass;

The daisies peep'd to see her pass, All on a summer morning.

Her pitcher she bore unto the well, That lay in the lap of a mossy dell, And her voice rang clear as a silver bell, The rival songbirds scorning.

But as she turn'd a hawthorne bush, A youth rush'd forth with speed so rash, That down came pitcher with a crash, And left her all a-mourning!

\footnotetext{
${ }^{98}$ Jane Turner Censer The Reconstruction of White Southern Womanhood, 1865-1895 (Baton Rouge: Louisiana State University Press, 2003), 15.
} 
"O, Sir! What have you done?

$\mathrm{Ah}$, me! Where shall I run?

My pitcher's gone! I had but one!

What will my mother say?"

"Stay, stay, my pretty maid!

Soon your pitcher shall be paid."

A golden piece in her hand be laid,

Bright as the summer morning!

But as he look'd upon her face,

He saw her simple, winsome grace;

Nor gold, nor pearls, nor priceless lace,

Her slender form adorning.

He saw the blush, the drooping lash,

And gazed, tho' gazing there was rash!

When snip and snap! His heart went crash,

And left him all a-mourning!

"O, maid! What have you done?

Quick! Quick! Home let us run!

My heart is gone! I had but one!

What will your own heart say? Ah, me!"

"O, sir! What have I done?

Quick! Quick! Homeward we'll run!

What's fairly done can't be undone,

And that's all my heart can say!"

On the surface, the text seems to convey an innocent encounter between the beautiful

young woman and a young man in which they fall in love at first sight, and this may have been

all the composer wished to convey when he chose the text for this song. At a closer glance, the broken pitcher seems to be a metaphor for virginity. The young woman runs into this man on her way to the well, intimacies are exchanged, and her "pitcher" is broken. She expresses her concern over what her mother will say and that she "had but one." The two find a solution to their problem, after he first attempts to pay her off, by declaring love for one another and rushing home, where they will inevitably share their intention to marry. The end of the song further 
supports this metaphor by stating, "what's fairly done can't be undone." The lovers have no other option than to marry. This is one of the few songs in the collection that Florence put her name to, perhaps indicating that it was a favorite of hers. Unfortunately, it cannot be known whether she saw it only for the simple love song it appears to be, or whether she contemplated deeper meaning behind the words.

The largest group in the Pond volume, the piano music consists mainly of dance pieces, including marches, polkas, and waltzes. There are several piano pieces published in different countries and bearing names in foreign languages, including a polka from collection of pieces called "Sylphen Leichten Tanzweisen," published by F.E.C. Leuckart in Breslau, Poland. Others are piano arrangements of music from classical works, including a gavotte from Gluck's Don Juan and music from Weber's Oberon. Florence's collection of piano music seems to represent a typical sheet music collection for a young woman of the nineteenth century, as Candace Bailey explains in Music and the Southern Belle..$^{99}$ Though Florence may not have been bound by the same social rules regarding appropriate music as young women in the South, she purchased her sheet music from the same publishers, so it makes sense that her collection would be similar to one from the South in that regard.

Due to the absence of text, it is harder to derive social meaning from the piano pieces in the collection, but some contemporary attitudes are expressed in in titles, on cover pages, and in musical material. Titles such as "The Honeymoon March" and "Belle of Chicago March" reveal the music publishing business's attempt at appealing to young women's interest. "The Honeymoon March," written by George Rosey and published by Joseph W. Stern and Company in New York in 1894, includes the phrase "To the Brides of the Season" on the front cover. The

\footnotetext{
${ }^{99}$ Bailey, 93-97.
} 
cover image shows a young couple, presumably just married and sightseeing on their honeymoon, standing on a cannon and looking at each other adoringly. A military official stands in the background, but the couples seem to ignore his presence. It is clear that this cover was designed to attract female consumers, particularly those with marriage on their minds. The music itself has a romantic quality as well. Though the title specifies that it is a march, it is written in a 6/8 meter and has the characteristic feel of a waltz. Charles Hamm explains the controversy over the waltz in Yesterdays. In the eighteenth and early nineteenth centuries, the waltz was considered improper for the intimacy displayed between people dancing it. The accompanying music was inappropriate by association. As the dance became more acceptable in the later nineteenth century, the waltz style in music came to represent romance in popular songs and piano music. ${ }^{100}$ This is precisely what "The Honeymoon March" attempts to do.

"The Belle of Chicago March" uses a similar tactic to appeal to young women with a title that might catch a young single woman's attention. This march was written by John Philip Sousa and published by Harry Coleman of Philadelphia in 1892. Though the cover does not feature a descriptive image like that of "The Honeymoon March," in includes a list of other compositions with titles that seem to appeal to young women with the same tactic. These titles include "Our Flirtation March," "Queen of the Harvest Quadrille," and "Beau Ideal March.”

There is no record of Florence having ever married. Though she was at most twenty-five at the time of her death, she would have been considered an old bride had she married then. These two pieces were published in the 1890s, when Florence was in her twenties and probably getting anxious about marriage. They might have caught her eye because of their themes of marriage and youth and filled her with hope that she too would marry someday. Or worse, thy

\footnotetext{
${ }^{100}$ Finson, 67.
} 
might have been gifts from family or friends who hoped she might take a hint and find herself a husband. Though one cannot know Florence's exact feelings on this matter, she must have felt pressure to marry, as she would have been seen as burden to her family for remaining unmarried and living with them.

Florence Pond's sheet music collection seems to stand as a foil to the Horner collection in several ways. The differing lifestyles of Florence and the Horner daughters can be seen in the kinds of music they collected as well as the size and content of their music collections. The Horner daughters, though from a prominent North Carolina family, were far from wealthy after the Civil War. This fact is apparent in their sheet music collections for its small size and notations that indicate a lower standard of musical education. On the other hand, there is no indication that Florence came from a prominent family. The facts of her life that can be traced in public records indicate that she and her family lived reasonably comfortably in the middle class. She had the time and resources to seek a thorough education in music, as indicated by the number of pieces in her collection and the number and difficulty of piano pieces. Overall, this sheet music collection can be used to make suggestions about Florence's life as a young woman in the postbellum North and, as I will discuss in my concluding remarks, serves as a foil to the Horner collection, which is in many ways representative of the postbellum South. 


\section{Conclusion}

The original purpose of this study was to look for common trends in sheet music collections of southern women and to use that information to understand what southern women in the postbellum South were communicating to their society based on the music they chose to play. The actual study upon completion has, I believe, shown much more than that. The music collections left behind by the Horner daughters and Florence Pond reveal much more than an impression of the kinds of music they liked to play. They reveal these young women's place within the worlds of which they were a part. My earliest thoughts on the approach I would take with this project were to study sheet music from a variety of collections and discuss postbellum music collections in a general sense, but it has turned out to be a more personal study of specific women whose stories can be told through the sheet music they left behind. It is my hope that, in conducting this study, I have given voices to these women who were not heard in their lifetimes.

It was by accident that I found the music collection of the Horner family's daughters. I chose it because it included a few interesting songs that I discovered upon browsing the Nineteenth-Century American Sheet Music Collection. Handwritten names on some of the pieces, those of Nina and Sophronia Horner, led me to conduct a search of census records to find out more about them. I was fortunate to find them, the members of an important family within the Oxford, North Carolina community. The men in this family are remembered for their contributions to the Horner School and their service to St. Stephen's Episcopalian Church. Their mother is remembered for her Civil War letters to her husband, which are held in Duke University Library's collections and have been discussed in studies such as that of Laura F. Edwards. The daughters, however, are rarely mentioned, and when they are, only their names are listed. 
Their sheet music collection has much to say about who these young women were. It must have been a financial challenge for James and Sophronia Horner, bringing up ten children in the postbellum South. The existence of the music collection suggests that they tried to educate their daughters in music, but the notations in some of the vocal music, as well as the dearth of piano music suggests that the daughters had only very basic musical training. It seems they were desperately holding on to the antebellum tradition of providing their daughters with such an education, but the strain of having seven daughters in an area having had its economic and class structures redefined as a result of the Civil War, hindered their ability to do so. The Horners were not a wealthy family, but they did occupy an elevated position in their community as members of the elite white social class. Even though they could not afford the luxury of a thorough musical education for their daughters, they still made the attempt to provide them with the means to present themselves as accomplished young women.

Indications of the Horner family's way of life can be seen in the music collection they left behind. They were a prominent North Carolina family working hard to keep up the image of respectability in a community where class and race lines were being redrawn. While they could no longer accomplish this with material wealth, they made up for it by holding positions of authority in their church and in the founding of their school. While James Horner and his sons put on the public face of respectability, the daughters stood in the background as examples of what elite white young women should be. They sang in church and owned several pieces of religious sheet music to sing at home, along with other appropriately-themed songs for young women of their class. Their collection contains only a few comic songs in which the content might be considered somewhat questionable. Otherwise, the Horner daughters would have sung mainly sentimental songs, many of them about love, romantic or motherly, and nostalgia for 
home. Given what Nancy Theriot has said about the importance of motherhood in nineteenthcentury thought on women, songs of this nature would have presented the Horner daughters as shining examples of aspiring womanhood.

It is difficult to say whether the Horner collection represents a typical southern collection from the postbellum period, but the information that can be gained from its content is in line with the scholarly literature on the topic. The Horner daughters' story is just one of many untold stories of nineteenth-century American women, but it is one that sheds light on the state of womanhood in the South after the Civil War. The music these women left behind seems to be the only window into their fascinating yet underappreciated lives.

I originally chose Florence Pond's collection because it contained types of pieces that could not be found in the Horner collection, that is, piano pieces and coon songs. A look into the content of the collection revealed several differences from the Horner collection that are noteworthy for this study. As I explained in chapter three, the size of the Pond collection indicates its owner was perhaps better able to afford to purchase sheet music for pleasure, and the large number of piano pieces suggests that the owner had studied the piano more thoroughly and thus had a more extensive musical education. When I discovered the census and legal records of Florence Pond, and found that she lived in the North, these differences began to make more sense. As Finson explains, minstrel and coon songs were immensely popular after the war, especially in the North, where blackface minstrelsy provided exotic entertainment. ${ }^{101}$ This explains the presence of such songs in Florence Pond's collection. Her location in above the Mason-Dixon Line as well as her proximity to New York City and its Tin Pan Alley publishers provide reasonable explanations for her consumption of this kind of sheet music. Several of the

${ }^{101}$ Finson, 200. 
coon songs in the collection express nostalgia for the lost rural paradise that was the antebellum South. As Florence's mother was born in South Carolina, she may have had a connection to the South and heard stories about it in its antebellum glory.

Though Florence Pond seems to have enjoyed a comfortable existence as the only child of a seemingly middle-class northern family, her life was not without hardship. As far as I can tell from records, she lived most of her life with her father, her mother seemingly out of the picture. She died at a young age, having never married, though the society she came from must have pressured her to do so. Mary Horner must have felt similarly pressured to marry, though she at least came from a family of educators who might have been more accepting of her decision to pursue a career as a teacher.

Florence seems to have been held to lower standards of feminine behavior, based upon the types of songs she collected. The coon songs indicate an interest in blackface minstrelsy that probably would not have been an acceptable form of entertainment for the Horner daughters. Their presence in Florence's collection suggests that she was under less pressure to be seen as a proper lady. She seems to have led a middle class kind of life where she was not held to strict rules of engagement. Her father's occupation as a clerk is the best indication of this. Because she did not live in a community redefining its class system, as the Horners did, she was probably more free to behave how she wanted.

What is perhaps most interesting about these two music collections and the people who owned them is that Florence Pond, though part of a lower class in her society than the Horner daughters, seems to have had better opportunities for musical education, as well as more financial security. This shows a drastic difference between the southern society that the Horners came from and the northern one in which Florence grew up. Though all of these young women 
were alive during the same time in American history, their situations differed greatly due to the class and gender expectations their societies held for them.

In leaving behind their music collections, these young women have provided a great opportunity for scholars of American history to have a closer look into the lives of everyday nineteenth-century women whose voices were stifled in their own time. It is by looking at the music they so meticulously collected and practiced that one can begin to get to know these women as people who had ideas and feelings about the state of their societies. By examining these pieces of themselves that these women have left behind, one can begin to understand their place within the world they called home. 


\section{Bibliography}

Abbott, Lynn and Doug Seroff. Ragged but Right: Black Traveling Shows, “Coon Songs, ” and the Dark pathway to Blues and Jazz. Jackson: University Press of Mississippi, 2009.

Abel, E. L. and Bobby Horton (Foreword). Singing the New Nation: How Music Shaped the Confederacy, 1861-1865. Mechanicsburg, PA: Stackpole, 2000.

Bailey, Candace. Music and the Southern Belle: From Accomplished Lady to Confederate Composer. Carbondale: Southern Illinois University Press, 2010.

Bardaglio, Peter W. Reconstructing the Household: Families, Sex, and the Law in the Nineteenth-Century South. Chapel Hill: University of North Carolina Press, 1995.

Barker-Benfield, G.J. The Horrors of the Half-Known Life: Male Attitudes toward Women and Sexuality in Nineteenth-Century America. New York: Routledge, 2000.

Bleser, Carol, ed. In Joy and In Sorrow: Women, Family, and Marriage in the Victorian South. New York: Oxford University Press, 1991.

Campbell, Gavin James. Music and the Making of a New South. Chapel Hill: University of North Carolina Press, 2004.

Carter, Christine Jacobson. Southern Single Blessedness: Unmarried Women in the Urban South, 1800-1865. Urbana: University of Illinois Press, 2006.

Censer, Jane Turner. The Reconstruction of White Southern Womanhood, 1865-1895. Baton Rouge: Louisiana State University Press, 2003.

Clinton, Catherine (Ed.) and Nina Silber (Ed.). Battle Scars: Gender and Sexuality in the American Civil War. New York: Oxford University Press, 2006.

Clinton, Catherine (Ed.) and Nina Silber (Ed.). Divided Houses: Gender and the Civil War. New York: Oxford University Press, 1992 
Cooke, Mary Lee. "Southern Women, Southern Voices: Civil War Songs by Southern Women." DMA diss. University of North Carolina Greensboro, 2007.

Cox, Karen L. Dreaming of Dixie: How the South Was Created in American Popular Culture. Chapel Hill: University of North Carolina Press, 2011.

Dennison, Sam. "Rosenfeld, Monroe H." in Grove Music Online. Oxford Music Online. http://www.oxfordmusiconline.com /article/grove/music/A2092678.

Edwards, Laura F. Gendered Strife and Confusion: The Political Culture of Reconstruction. Urbana: University of Illinois Press, 1997.

Emerson, Ken. Doo-Dah! Stephen Foster and the Rise of American Popular Culture. New York: Simon \& Schuster, 1997.

Find a Grave. http://www.findagrave.com.

Finson, Jon W. The Voices That Are Gone: Themes in Nineteenth-Century American Popular Song. New York: Oxford University Press, 1997.

Fox-Genovese, Elizabeth . Within the Plantation Household: Black and White Women of the Old South. Chapel Hill: University of North Carolina Press, 1988.

Gevinson, Alan. "Silverites, Populists, and the Movement for Free Silver." TeachingHistory.org, National History Education Clearinghouse. http://teachinghistory.org/history-content/aska-historian/25222 (accessed 4 Nov. 2015).

Glymph, Thaviola. Out of the House of Bondage: The Transformation of the Plantation Household. New York: Cambridge University Press, 2008.

Hamm, Charles. Yesterdays: Popular Song in America. New York: Norton, 1979. 
"Harry Beard Collection." Victoria and Albert Museum.

http://collections.vam.ac.uk/item/O1157185/harry-beard-collection-sheet-music-randallharry/ (accessed 4 Nov. 2015).

Horner, Frederick. The History of the Blair, Banister, and Braxton Families Before and After the Revolution with a Brief Sketch of Their Descendents. Philadelphia: J. B. Lippencott, 1898.

Jabour, Anya. Scarlett's Sisters: Young Women in the Old South. Chapel Hill: University of North Carolina Press, 2007.

Jackson, Charles O., ed. Passing: The Vision of Death in America. Contributions in Family Studies, vol. 2. Westport, CT: Praeger, 1977.

Janiewski, Dolores E. Sisterhood Denied: Race, Gender, and Class in a New South Community. Philadelphia: Temple University Press, 1985.

Levine, Bruce. The Fall of the House of Dixie: The Civil War and the Social Revolution that Transformed the South. New York: Random House, 2013.

McWhirter, Christian. Battle Hymns: The Power and Popularity of Music in the Civil War. Chapel Hill: University of North Carolina Press, 2012.

Moseley, Caroline. "Irrepressible Conflict: Differences between Northern and Southern Songs in the Civil War." Journal of Popular Culture 25, no. 2 (Fall 1991): 45-46.

New Jersey. Union County. 1880 U.S. Census, population schedule. Digital images. Ancestry.com, accessed 4 Nov. 2015. http://ancestry.com.

New Jersey. Union County. 1880 U.S. Census, population schedule. Digital images. Ancestry.com, accessed 4 Nov. 2015. http://ancestry.com. 
New Jersey. Union County. 1895 State Census, population schedule. Digital images.

Ancestry.com, accessed 4 Nov. 2015. http://ancestry.com.

New Jersey. Somerset County. Probate Records. New Jersey Surrogate’s Court, Somerville. Nineteenth-Century American Sheet Music Collection. Music Library. University of North Carolina Chapel Hill. http://dc.lib.unc.edu/cdm/landingpage/collection/sheetmusic.

North Carolina. Granville County. 1860 U.S. Census, population schedule. Digital images. Ancestry.com, accessed 4 Nov. 2015. http://ancestry.com.

North Carolina. Granville County. 1870 U.S. Census, population schedule. Digital images. Ancestry.com, accessed 4 Nov. 2015. http://ancestry.com.

North Carolina. Granville County. 1880 U.S. Census, population schedule. digital images. Ancestry.com, accessed 4 Nov. 2015. http://ancestry.com.

North Carolina. Granville County. 1900 U.S. Census, population schedule. Digital images. Ancestry.com, accessed 4 Nov. 2015. http://ancestry.com.

North Carolina. Wake County. 1880 U.S. Census, population schedule. Digital images. Ancestry.com, accessed 4 Nov. 2015. http://ancestry.com.

Ott, Victoria E. Confederate Daughters: Coming of Age during the Civil War. Carbondale: Southern Illinois University Press, 2008.

Perman, Michael. Pursuit of Unity: A Political History of the American South. Chapel Hill: University of North Carolina Press, 2009.

Powell, William S. “Horner, James Hunter.” NCPedia. http://ncpedia.org/biography/hornerjames-hunter (accessed 4 Nov. 2015).

Roberts, Giselle. The Confederate Belle. Columbia: University of South Carolina Press, 2003. 
Scott, Anne Firor. The Southern Lady: From Pedestal to Politics 1830-1930. Chicago: University of Chicago Press, 1970.

Schultz, Kirsten Marelle. "Secessia's Song Books: The History of Confederate Songsters." PhD diss. University of Toronto, 2002.

Theriot, Nancy M. Mothers and Daughters in Nineteenth Century America: The Biosocial Construction of Femininity. Lexington: University Press of Kentucky, 1996.

Whites, LeeAnn. Gender Matters: Civil War, Reconstruction, and the Making of the New South. New York: Palgrave MacMillan, 2005.

Whitesitt, Linda. "'The Most Potent Force' in American Music: The Role of Women's Music Clubs in American Concert Life." In The Musical Woman: An International Perspective III: 1986-1990, 663-681. Westport, CT: Greenwood Press, 1991. 